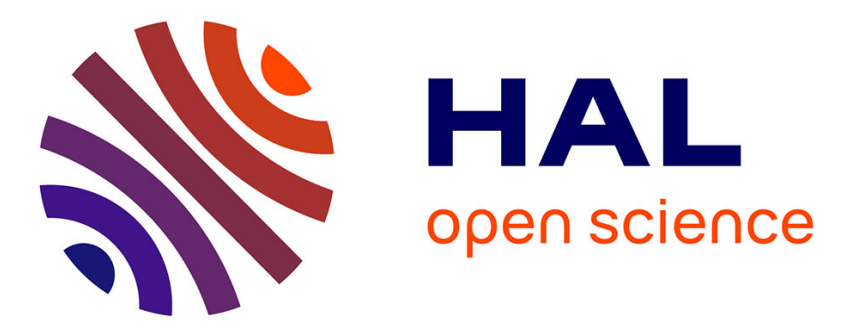

\title{
A hypothalamo-midbrain-medullary pathway involved in the inhibition of the respiratory chemoreflex response induced by potassium cyanide in rodents
}

Tabinda Zafar, Charly Brouillard, Laurence Lanfumey, Caroline Sévoz-Couche

\section{- To cite this version:}

Tabinda Zafar, Charly Brouillard, Laurence Lanfumey, Caroline Sévoz-Couche. A hypothalamomidbrain-medullary pathway involved in the inhibition of the respiratory chemoreflex response induced by potassium cyanide in rodents. Neuropharmacology, 2017, 10.1016/j.neuropharm.2017.09.036 . hal-01615236

\section{HAL Id: hal-01615236 \\ https: / hal.sorbonne-universite.fr/hal-01615236}

Submitted on 12 Oct 2017

HAL is a multi-disciplinary open access archive for the deposit and dissemination of scientific research documents, whether they are published or not. The documents may come from teaching and research institutions in France or abroad, or from public or private research centers.
L'archive ouverte pluridisciplinaire HAL, est destinée au dépôt et à la diffusion de documents scientifiques de niveau recherche, publiés ou non, émanant des établissements d'enseignement et de recherche français ou étrangers, des laboratoires publics ou privés. 


\section{Accepted Manuscript}

A hypothalamo-midbrain-medullary pathway involved in the inhibition of the respiratory chemoreflex response induced by potassium cyanide in rodents

Tabinda Zafar, Charly Brouillard, Laurence Lanfumey, Caroline Sévoz-Couche

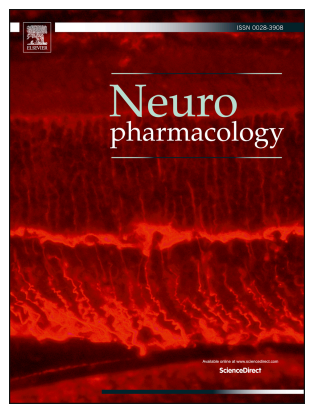

PII:

S0028-3908(17)30453-7

DOI:

10.1016/j.neuropharm.2017.09.036

Reference: NP 6880

To appear in: Neuropharmacology

Received Date: 18 May 2017

Revised Date: 7 September 2017

Accepted Date: 26 September 2017

Please cite this article as: Zafar, T., Brouillard, C., Lanfumey, L., Sévoz-Couche, C., A hypothalamomidbrain-medullary pathway involved in the inhibition of the respiratory chemoreflex response induced by potassium cyanide in rodents, Neuropharmacology (2017), doi: 10.1016/j.neuropharm.2017.09.036.

This is a PDF file of an unedited manuscript that has been accepted for publication. As a service to our customers we are providing this early version of the manuscript. The manuscript will undergo copyediting, typesetting, and review of the resulting proof before it is published in its final form. Please note that during the production process errors may be discovered which could affect the content, and all legal disclaimers that apply to the journal pertain. 

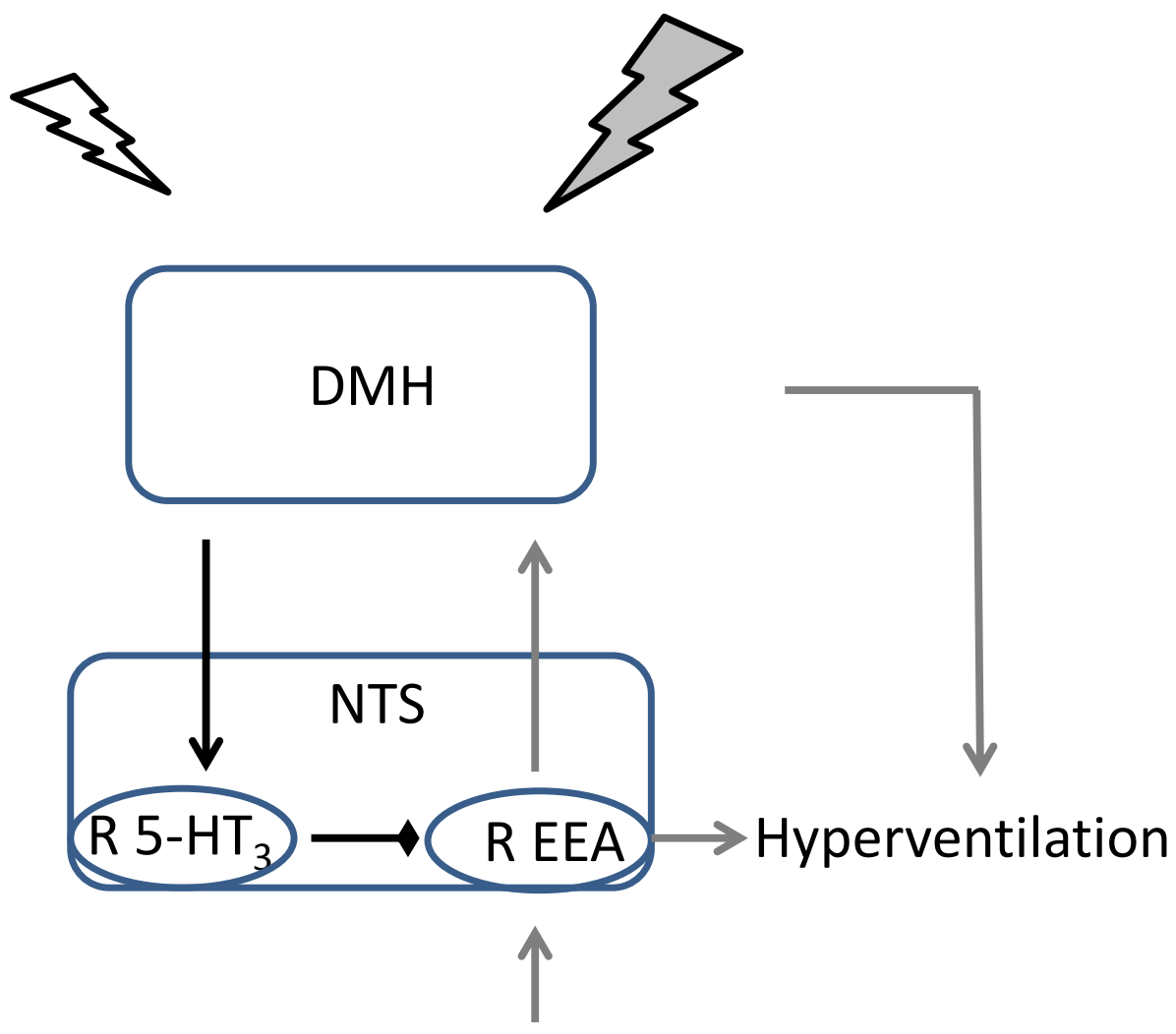

Peripheral chemoreflex

$\rightarrow$ Excitatory inputs

$\longrightarrow$ Inhibitory inputs

Mild stimulation

Strong stimulation 
A hypothalamo-midbrain-medullary pathway involved in the inhibition of the respiratory chemoreflex response induced by potassium cyanide in rodents

Tabinda Zafar, Charly Brouillard, Laurence Lanfumey and Caroline Sévoz-Couche

Sorbonne Universités, UPMC Univ Paris 06, INSERM, UMR_S 1158, Neurophysiologie Respiratoire Expérimentale et Clinique, F-75005, Paris, France

\section{Corresponding author:}

Caroline Sévoz-Couche,

Faculté de médecine UPMC, Site Pitié-Salpêtrière, 91 bd de l'Hôpital, Paris F-75013, France Fax: +33140779790

Phone: + 33140779763

E-mail address: caroline.sevoz-couche@upmc.fr

Total word-count : 7484 


\section{Abstract}

Recent studies have demonstrated that a mild stimulation of the dorsomedian nucleus of the hypothalamus (DMH), a defense area, induces the inhibition of the carotid chemoreflex tachypnea. DMH activation reduces the cardiac chemoreflex response via the dorsolateral part of the periaqueductal grey matter (dIPAG) and serotonin receptors $\left(5-\mathrm{HT}_{3}\right.$ subtype) in the nucleus tractus solitarius (NTS). The objectives of this study were to assess whether dIPAG and subsequent NTS 5- $\mathrm{HT}_{3}$ receptors are involved in chemoreflex tachypnea inhibition during mild activation of the $\mathrm{DMH}$. For this purpose, peripheral chemoreflex was activated with potassium cyanide $(\mathrm{KCN}, 40 \mu \mathrm{g} / \mathrm{rat}$, i.v.) during electrical and chemical minimal supra-threshold (mild) stimulation of the dIPAG or DMH. In both situations, changes in respiratory frequency (RF) following $\mathrm{KCN}$ administration were reduced. Moreover, pharmacological blockade of the dIPAG prevented DMH-induced KCN tachypnea inhibition. Activation of NTS $5-\mathrm{HT}_{3}$ receptors also reduced chemoreflex tachypnea in a dose-dependent manner. In addition, blockade of NTS $5-\mathrm{HT}_{3}$ receptors with granisetron (2.5 but not 1.25 $m M)$, or the use of mice lacking the $5-\mathrm{HT}_{3 \mathrm{a}}$ receptor $\left(5-\mathrm{HT}_{3 \mathrm{a}} \mathrm{KO}\right)$, prevented dIPAG-induced $\mathrm{KCN}$ reductions in RF. A respiratory hypothalamo-midbrain-medullary pathway (HMM) therefore plays a crucial role in the inhibition of the hyperventilatory response to carotid chemoreflex.

Keywords: carotid chemoreflex, hypothalamus, respiratory responses, nucleus tractus solitarius, $5-\mathrm{HT}_{3}$ receptor 
1. Introduction

Several nuclei in the hypothalamus, including the dorsmedian nucleus of the hypothalamus $(\mathrm{DMH})$, constitute a brain aversive system that coordinates aggressive or defense-type behavioral patterns (Bandler et al., 2000; Sévoz-Couche et al., 2003). The defense reaction, which is elicited in anesthetised animals by either electrical or chemical stimulation of the hypothalamic sites, triggers most of the effect observed in awake animals (Sévoz-Couche et al., 2003); examples include exophthalmos and whisker movements associated with blood flow redistribution among organs, and both hypertension and tachycardia in response to sympathetic activation (Bandler and Carrive, 1988; Bandler et al., 2000; Smith et al., 1990). The dorsolateral part of the periaqueductal grey (dIPAG) also plays a pivotal role in the defense reaction (Bandler and Carrive, 1988). The defense reaction is associated with an inhibition of the baro- and chemo-reflex bradycardia, via activation of nucleus tractus solitarius (NTS) 5- $\mathrm{HT}_{3}$ receptors (Netzer et al., 2009, 2011). Both DMH and dIPAG acute and intense stimulation also mediate a tachypnea, possibly by direct projections to dorsal pons respiratory centers (Hayward and Castellanos, 2003; Johnson et al., 2008).

Clinical studies have shown that panic disorder is associated with symptoms that include palpitations, shortness of breath, sweating and hyperventilation (Abelson et al., 2010). High levels of anxiety-related behaviour in rats are also associated with an elevation of the resting respiratory rate (Carnevali et al., 2013), whilst an intense neonatal emotional stress such as maternal separation, triggers a long-term decrease in breathing rate during non-REM sleep (Kinkead et al., 2009). However, recent results have shown that social defeat (a validated model of repeated confrontation in rats inducing ultrasonic vocalisations and freezing) generates a decrease in basal respiratory frequency, mediated by low and long-term $\mathrm{DMH}$ induced NTS 5- $\mathrm{HT}_{3 a}$ receptor stimulation (Brouillard et al., 2016). As a result of chemodenervation, basal breathing frequency is diminished (Hayward, 2001; Izumizaki et al., 2004). Chronic reduction of chemoreflex respiratory responses may occur in social defeat and be the origin of the long-term decrease in respiratory frequency (RF).

We have recently demonstrated that minimal $\mathrm{DMH}$ supra-threshold stimulation depresses the respiratory component of the peripheral chemoreflex induced by $\mathrm{KCN}$ administration (Zafar et al., 2015). 
The purpose of the present study was to evaluate in rodents $i$ ) the role of the dIPAG in DMHinduced inhibition of the carotid respiratory response, and ii) the role of NTS $5-\mathrm{HT}_{3 a}$ receptors in the inhibitory effect of dIPAG stimulation on the $\mathrm{KCN}$-induced respiratory response.

2. Material and methods

\subsection{General procedures}

All animals were kept under controlled environmental conditions $\left(22 \pm 1^{\circ} \mathrm{C} ; 60 \%\right.$ relative humidity; alternating circadian rhythms with light (7 h-19 h) and dark (19 h-7 h); access to food and water (ad libitum). Procedures involving animals and their care were all conducted in accordance with institutional guidelines, which are in compliance with European Directives (2010/63/EU). Experimental permission ( $\left.N^{\circ} 75855\right)$ was given by the Ministere de l'Agriculture et de la Foret, Service Veterinaire de la Sante et de la Protection Animale, to C. Sévoz-Couche.

Experiments were mostly performed in male Sprague-Dawley rats weighing 330350g ( $n=76$, Breeding Center R. Janvier, Le Genest St.Isle, France). Some experiments were also performed using male homozygous $5 \mathrm{HT}_{3} \mathrm{KO}(n=5)$ and wild-type $(W T, n=5)$ littermates mice born from heterozygous mutants on a C57BL/6J genetic background (>10 generations), and genotyped as described by Zeitz (Zeitz et al., 2002). Animals were anesthetised using urethane $(1.5 \mathrm{~g} / \mathrm{kg}$, i.p.). The depth of anesthesia was regularly assessed by pinching a hind paw and monitoring the stability of arterial blood pressure and heart rate recordings. Rectal temperature was maintained at $37^{\circ} \mathrm{C}$ using a thermostatically-controlled heating blanket. In all animals, polyethylene cannulas were introduced into the femoral artery for recording haemodynamic variables and controlling animal stability, and into the vein for administration of KCN or additional doses of urethane. In cases of withdrawal reflex and/or significant variations of these parameters, a supplementary dose of urethane was given (1 $\mathrm{mg} / \mathrm{kg}$, i.v.)

\subsection{Respiratory measurements}


The trachea was cannulated to monitor respiration (Zafar et al., 2015). The cannula was connected to a pneumotachograph (Fleisch 0000), which related to a volume transducer (Digitimer Neurolog, NL 905). Respiratory signals were relayed to a 1401 interface (1401 Plus, CED, UK) and processed by Spike 2 Software (6.14, CED, UK). Both RF and tidal volume $\left(V_{T}\right)$ were derived from the ventilatory flow signal.

\subsection{DMH and dIPAH}

Anaesthetised rats were placed in a stereotaxic frame, and the dorsal surface of the brainstem was exposed such that the skull was horizontal between bregma and lambda. Stimulations of the DMH and the dIPAG were performed in rats at the following stereotaxic coordinates (from bregma): AP -3.0, L 1.0, V 8 and AP -7.0, L 1.0, V 4, respectively (SévozCouche et al., 2003). Mild ("minimal suprathreshold") DMH and dIPAG activation, sufficient to induce small modifications in heart rate (HR) and arterial blood pressure ( $A B P)$ but no arousal respiratory responses, was elicited by low $(30 \mu \mathrm{A})$ electrical stimulation (bipolar electrode, $15 \mathrm{sec}, 50 \mathrm{~Hz}, 1 \mathrm{~ms}$ pulse duration). Because of the numerous GABAergic inputs these regions receive and in particular the $\mathrm{DMH}$, slight chemical desinhibition seemed to be appropriate to produce minimal excitation (Zaretskaia et al., 2008). Thus we microinjected locally bicuculline methiodide to stimulate these regions but at a lower dose $(5 \mathrm{pmol}$ in 100 $\mathrm{nl}$ ) than used before (Comet et al., 2004; Netzer et al., 2011). In WT and 5-HT $\mathrm{Ha}_{3} \mathrm{KO}$ mice, mild $(20 \mu \mathrm{A})$ electrical current (15 sec, $50 \mathrm{~Hz}, 1 \mathrm{~ms}$ pulse duration), sufficient to induce small cardiovascular modifications but no arousal respiratory responses, was applied to activate dIPAG (AP -4.2, L 0.5, V $1.8 \mathrm{~mm}$ from bregma).

Inhibition of the dIPAG in rats was obtained by bilateral microinjection of muscimol (500 pmol in $100 \mathrm{nl}$ ), a selective agonist of $\mathrm{GABA}_{A}$ receptors (Sévoz-Couche et al., 2003). Sham electrical and chemical procedures were performed using zero electrical current or vehicle (saline) microinjection, respectively.

\subsection{NTS microinjections}

NTS $5-\mathrm{HT}_{3}$ receptors were activated by bilateral microinjection of $\mathrm{m}$-chlorophenylbiguanide (CPBG, 0.1 to $1.6 \mathrm{nmol}$ in $100 \mathrm{nl}$, Sigma Aldrich, St Louis, USA), or blocked 
by bilateral microinjection of granisetron (125 and $250 \mathrm{pmol}$ in $100 \mathrm{nl}$, SmithKline-Beecham, Harlow, UK), at the following coordinates from the calamus scriptorius ( $P-0.5, L 0.5$ and V $0.5 \mathrm{~mm}$ ) (Sévoz et al., 1997). In all cases, the microinjected vehicle was saline. Only one dose of CPBG or granisetron was microinjected per rat.

\subsection{Carotid chemoreceptor reflex activation}

This reflex was induced in rats and mice by injections of $\mathrm{KCN}(40 \mu \mathrm{g} / \mathrm{rat}$ and 4 $\mu \mathrm{g} /$ mice, $0.1 \mathrm{ml}$ ) into the femoral and jugular vein, respectively, at least $30 \mathrm{~min}$ after induction of anesthesia. Activation of carotid bodies results in hyperventilation, assessed by an increase in RF and $V_{T}$. KCN was given either during electrical ( $3 \mathrm{sec}$ after the beginning of application) or after chemical ( $5 \mathrm{~min}$ after bicuculline microinjections) activation of the studied area, when the small cardiovascular modifications reached their maximal values. The time interval between tests was greater than $10 \mathrm{~min}$ to achieve reproductibility of chemoreflex respiratory responses. We verified that chemodenervation (bilateral resection of carotid bodies) abolishes respiratory responses, as we have demonstrated previously (Zafar et al., 2015).

\subsection{Experimental design (Fig 1 and 2)}

Experiment 1: Does dIPAG blockade reverse the inhibitory action of low electrical (A) and chemical (B) stimulation of the DMH on $\mathrm{KCN}$-induced respiratory responses in rats?

1A. KCN was administered during sham or experimental DMH electrical stimulation in the same animal, either $10 \mathrm{~min}$ after intra-dIPAG vehicle or $10 \mathrm{~min}$ after intra-dIPAG muscimol.

1B. KCN was administered during sham or experimental DMH chemical stimulation in the same animal, 10 min after either intra-dIPAG vehicle or intra-dIPAG muscimol.

Experiment 2: Does low electrical (A) or chemical (B) dIPAG stimulation exert an inhibitory action on $\mathrm{KCN}$-induced respiratory responses in rats?

2A. KCN was administered: firstly, during sham dIPAG electrical stimulation, then, in the same animal, during experimental dIPAG electrical stimulation. 
2B. KCN was administered: firstly, 5 min after sham dIPAG chemical stimulation, then, in the same animal, $5 \mathrm{~min}$ after experimental dIPAG chemical stimulation (bicuculline microinjection).

Experiment 3: Does NTS 5- $\mathrm{HT}_{3}$ receptor inhibition reverse the negative influence exerted by low electrical stimulation of the dIPAG on $\mathrm{KCN}$-induced respiratory responses in rats?

KCN was administered during sham or experimental dIPAG electrical stimulation in the same animal, 10 min after either intra-NTS vehicle or intra-NTS granisetron.

Experiment 4: Does the 5- $\mathrm{HT}_{3 \mathrm{a}}$ receptor exert a role in the effects of low electrical activation of the dIPAG on KCN-induced respiratory responses in mice?

4A. KCN was administered: firstly, during sham dIPAG electrical stimulation, then, in the same animal, during experimental dIPAG electrical stimulation in WT mice.

4B. KCN was administered: firstly, during sham dIPAG electrical stimulation, then, in the same animal, during experimental dIPAG electrical stimulation in genetically modified mice lacking the $5-\mathrm{HT}_{3 a}$ receptor $\left(5-\mathrm{HT}_{3 \mathrm{a}} \mathrm{KO}\right)$.

Experiment 5: Does NTS 5- $\mathrm{HT}_{3}$ receptor activation exert an inhibitory effect on $\mathrm{KCN}$ induced respiratory responses in rats?

5A. KCN was administered in different animals $10 \mathrm{~min}$ after either intra-NTS vehicle or different doses of CPBG .

5B. KCN was administered: firstly, $10 \mathrm{~min}$ after intra-NTS vehicle, then, in the same animal, $10 \mathrm{~min}$ after intra-NTS CPBG preceded ( $2 \mathrm{~min}$ ) by intra-granisetron.

\subsection{Histological localization of microinjection sites}

At the end of the experiments, the animals were killed with an i.v. overdose of urethane. The brain was removed and fixed in $10 \%$ formalin solution and cryoprotected in $20 \%$ sucrose solution for 5 days. Microinjection sites were identified in $50 \mu \mathrm{m}$ thick sections 
of brain tissue by the the track of the micropipette in the DMH or deposit of Pontamine sky blue (Netzer et al., 2011) in the dIPAG and the NTS. The dye spread was inferior or equal to $500 \mu \mathrm{m}$, as found previously (Comet et al., 2004, 2007; Sévoz-Couche et al., 1998).

\subsection{Data Analysis}

Normality was evaluated by the Shapiro-Wilk test. In rats and mice, respiratory responses to repeated $\mathrm{KCN}$ administrations in the same animal were compared using paired t test ANOVA for two, and one way RM ANOVA for three KCN injections. Multiple Scheffé's comparison was used to evaluate the dose-dependent effects of CPBG (one dose per animal) on $\mathrm{KCN}$ respiratory responses. The effects of active substances on baseline respiratory parameters in rats were performed using unpaired $t$ test ANOVA. Comparisons of baseline respiratory parameters and $\mathrm{KCN}$ responses in WT and 5- $\mathrm{HT}_{3 \mathrm{a}} \mathrm{KO}$ mice were performed using unpaired $t$ test ANOVA.

Analyses were performed using SigmaPlot 12.0. All results were considered significant if $p<0.05$. All values are means \pm SEM.

\section{Results}

Basal cardiovascular and respiratory parameters of the rats and mice are noted in Table 1.

\section{Experiment 1: Does dIPAG blockade reverse the inhibitory action of low electrical (A) and chemical (B) stimulation of the DMH on $\mathrm{KCN}$-induced respiratory responses in rats?}

Microinjections of bicuculline into the $\mathrm{DMH}$, and muscimol into the dIPAG, were performed in the following experiments. None of these treatments produced modifications in baseline cardiorespiratory parameters (Table 2).

Experiment 1A: When intra-dIPAG vehicle was used, the reflex increase in RF induced by intravenous administration of KCN was lower when induced simultaneously to minimal $(30 \mu \mathrm{A})$ suprathreshold activation (mild electrical stimulation) of the $\mathrm{DMH}$ than during sham $\mathrm{DMH}$ activation $(+10 \pm 2$ and $+42 \pm 6 \mathrm{cpm}$, respectively, $p=0.004, \mathrm{n}=6$, Fig $3 \mathrm{~A})$. The inhibitory effect of the $\mathrm{DMH}$ was prevented by muscimol microinjection into the dIPAG $(p=0$. 70, Fig 
3A). In the same animals, the reflex increase in $\mathrm{V}_{\mathrm{T}}$ was similar during sham or electrical $\mathrm{DMH}$ activation after intra-dIPAG vehicle $(+1.3 \pm 0.3$ and $+1.1 \pm 0.4 \mathrm{ml}$, respectively, $p=0.25)$, and during electrical DMH activation after intra-dIPAG vehicle or muscimol $(+1.4 \pm 0.3$ and $+1.3 \pm 0.5 \mathrm{ml}$, respectively, $\mathrm{p}=0.68$, Fig $3 \mathrm{~A}$ ).

Experiment 1B: When intra-dIPAG vehicle was used, $\triangle \mathrm{RF}$ induced by $\mathrm{KCN}$ was lower when induced 5 min after bicuculline injection into the $\mathrm{DMH}$ vs vehicle $(-5 \pm 2$ and $+38 \pm 4 \mathrm{cpm}$, respectively, $p=0.001, n=6$, Fig $3 B$ ). This inhibitory effect induced by $\mathrm{DMH}$ activation was prevented when muscimol was microinjected into the dIPAG ( $p=0.0005$, Fig $3 B$ ). In the same animals, the reflex increase in $\mathrm{V}_{\mathrm{T}}$ was similar during sham or chemical $\mathrm{DMH}$ activation after intra-dIPAG vehicle $(+1.42 \pm 0.21$ and $+1.21 \pm 0.21 \mathrm{ml}$, respectively, $\mathrm{p}=0.65)$, and during chemical DMH activation after intra-dIPAG vehicle or muscimol $(+1.2 \pm 0.4$ and $+1.4 \pm 0.2 \mathrm{ml}$, respectively, $p=0.65$ ) (Fig 3B). Representative responses of $\mathrm{RF}$ and $\mathrm{V}_{\mathrm{T}}$ to $\mathrm{KCN}$ administration during these different experimental conditions are shown in Fig 4 and a representative microinjection into the dIPAG is shown in Fig 5.

Experiment 2: Does low electrical (A) and chemical (B) dIPAG stimulation exert an inhibitory action on $\mathrm{KCN}$-induced respiratory responses in rats?

Experiment 2A: The magnitude of $\triangle \mathrm{RF}$ was smaller when $\mathrm{KCN}$ was administered simultaneously minimal suprathreshold activation (mild electrical stimulation) of the dIPAG vs no passing current $(-7 \pm 5$ and $+34 \pm 4 \mathrm{cpm}$, respectively, $p<0.001, n=5$, Fig $6 \mathrm{~A})$. In the same animals, the increase in $\mathrm{V}_{\mathrm{T}}$ due to $\mathrm{KCN}$ administration was similar during both conditions $(+1.32 \pm 0.21$ and $+1.34 \pm 0.20 \mathrm{ml}$, respectively, $p=0.45$, Fig $6 \mathrm{~A})$.

Experiment 2B: Reflex $\triangle \mathrm{RF}$ was smaller when $\mathrm{KCN}$ was administered $5 \mathrm{~min}$ after intradIPAG bicuculline (Fig $6 \mathrm{~B})$, than by vehicle $(-2 \pm 1$ and $+34 \pm 5 \mathrm{cpm}$, respectively, $p<0.001$, $p<0.001, \mathrm{n}=7)$. In the same animals, reflex $\Delta \mathrm{V}_{\mathrm{T}}$ was similar whether $\mathrm{KCN}$ was administered after intra-dIPAG bicuculline or by vehicle $(+0.94 \pm 0.10$ and $+1.07 \pm 0.18 \mathrm{ml}$, respectively, $p=0.07$, Fig 6B). Microinjections of bicuculline into the dIPAG didn't produce any modifications in baseline cardiorespiratory parameters (Table 2).

Experiment 3. Does NTS $5-\mathrm{HT}_{3}$ receptor inhibition reverse the negative influence exerted 
by low electrical stimulation of the dIPAG on KCN-induced respiratory responses in rats?

Microinjections of granisetron 125 and 250 pmol into the NTS were performed in the following experiments, and produced no modifications in baseline cardiorespiratory parameters (Table 2). Compared to sham, electrical dIPAG stimulation induced an inhibition of control $K C N$-induced $\triangle R F$ after intra-NTS vehicle $(+5 \pm 8$ and $+58 \pm 8 \mathrm{cpm}$, respectively, $p=0.002, \mathrm{n}=6$, Fig 7A) that was not reversed after intra-granisetron at the dose of $125 \mathrm{pmol}$ (Fig 7A). The reflex increase in $V_{T}$ was not statistically different between control and electrical dIPAG activation after intra-NTS vehicle $(p=0.75)$, was well as during electrical dIPAG activation after intra-dIPAG vehicle or granisetron $125 \mathrm{pmol}(\mathrm{p}=0.38)$. In a second series of experiments, the inhibitory effect of chemoreflex $\triangle \mathrm{RF}$ response during dIPAG stimulation compared to sham after intra-NTS vehicle administration $(+2 \pm 3$ and $+48 \pm 10 \mathrm{cpm}$, respectively, $\mathrm{p}<0.001$ ) was prevented when $\mathrm{NTS} 5-\mathrm{HT}_{3}$ receptors were blocked by granisetron at a dose of $250 \mathrm{pmol}\left(p=0.70, n=6\right.$, Fig 7B). The reflex increase in $V_{T}$ was not statistically different between control and electrical dIPAG activation after intra-NTS vehicle $(p=0.78)$, and during electrical dIPAG activation after intra-NTS vehicle or granisetron 250 pmol $(p=0.48)$. Representative responses of RF and $V_{T}$ to $K C N$ administration after intra-NTS vehicle or granisetron 250 pmol are shown in Fig 8.

Experiment 4. Does the $5-\mathrm{HT}_{3}$ receptor exert a role in the effects of low electrical activation of the dIPAG on $\mathrm{KCN}$-induced respiratory responses in mice?

There was no statistical difference in basal RF $(p=0.35)$ and $\mathrm{V}_{\mathrm{T}}(p=0.16)$, nor in $\mathrm{KCN}$ respiratory responses (RF: $\mathrm{p}=0.75$ and $\mathrm{V}_{\mathrm{T}}: p=0.32$ ), between $\mathrm{WT}$ and $5-\mathrm{HT}_{3 a} \mathrm{KO}$ mice. The magnitude of the reflex $\triangle \mathrm{RF}$ was smaller when $\mathrm{KCN}$ was administered during mild electrical dIPAG stimulation vs no passing current (sham) in WT (Experiment $4 A,+10 \pm 2$ and $+30 \pm 3$ cpm, respectively, $p=0.008, n=5$; Figs $9 \mathrm{~A}$ and $10 \mathrm{~A})$, but not in $5-\mathrm{HT}_{3 \mathrm{a}} \mathrm{KO}(+24 \pm 2$ and $+22 \pm 3$ cpm, respectively, $p=0.62, n=5$; Figs $9 B$ and $10 B$ ) mice. In the same animals, when $K C N$ was administered, $\Delta \mathrm{V}_{\mathrm{T}}$ was similar under both experimental conditions, either in WT $(+0.50 \pm 0.09$ and $+0.35 \pm 0.11 \mathrm{ml}$, respectively, $p=0.17$; Fig $9 \mathrm{~A}$ and $10 \mathrm{~A})$ or $\mathrm{KO}(+0.37 \pm 0.07$ and $+0.48 \pm 0.11$ $\mathrm{ml}$, respectively, $p=0.08$, Fig $9 \mathrm{~B}$ and $10 \mathrm{~B}$ ) mice.

Experiment 5. Does NTS 5-HT $\mathrm{H}_{3}$ receptor activation exert an inhibitory effect on $\mathrm{KCN}$ - 


\section{induced respiratory responses in rats?}

Experiment 5A: Microinjections into the NTS (Fig 3B) of vehicle $(n=5)$ or different doses of CPBG (0.1 to $1.6 \mathrm{nmol}, \mathrm{n}=5$ each) were performed in the following experiments. None of these treatments produced modifications in RF, VT and HR but induced an increase in $A B P$ when the dose was equal or superior to $0.8 \mathrm{nmol}$ (Table 2). Compared to vehicle, activation of $\mathrm{NTS} 5-\mathrm{HT}_{3}$ receptors by CPBG $(\geq 0.4 \mathrm{nmol})$ produced a dose-dependent inhibitory effect on $\mathrm{KCN}$-induced $\triangle \mathrm{RF}$ (Fig 11), with a maximal effect at $0.4 \mathrm{nmol}$ (Fig 11 and 12). In animals that received vehicle and CPBG $(0.4 \mathrm{nmol}), \mathrm{KCN}$-induced increase in $\mathrm{V}_{\mathrm{T}}$ was comparable under both conditions $(+1.22 \pm 0.11$ and $+0.77 \pm 0.10 \mathrm{ml}$, respectively, $p=0.7$; Fig 12).

Experiment 5B: After prior intra-NTS microinjection of granisetron at a dose of 250 pmol but not $125 \mathrm{pmol}$, the $\mathrm{KCN}$-induced increase in RF both after CPBG (0.4 nmol) and vehicle administration $(+35 \pm 3$ and $+38 \pm 8 \mathrm{cpm},+30 \pm 3$ and $+41 \pm 8 \mathrm{cpm}$, respectively, $p=0.34$, $\mathrm{n}=5$; respectively, $p=0.78, \mathrm{n}=5$ ).

\section{Discussion}

The carotid body contains specialised type I cells that contain oxygen sensors. Type I cells depolarise in response to hypoxia, but also respond to hypercapnia, changes in $\mathrm{pH}$, temperature, osmolality and glucose, and are important in promoting arousal (Izumizaki et al., 2004). Stimulation of these cells may also be obtained by intra-venous administration of KCN (Netzer et al., 2009). Cyanide $\left(\mathrm{CN}^{-}\right)$is toxic due to its chemical binding to cytochrome $c$ oxidase, which blocks the mitochondrial electron transport chain and subsequently inhibits tissue aerobic respiration (Isom et al., 1982). Transient hypoxia and cyanide stimulation of the carotid bodies cause similar neural responses in cats and rats, including a profound activation of the minute ventilation and phrenic nerve discharge (Gonzalez et al., 1977; Izumizaki et al., 2004; Koshiya and Guyenet, 1994; Purves, 1966) , and their excision causes chronic hypoventilation (Hayward, 2001; Olson et al., 1988).

Chemosensitive neurons in the medullary retrotrapezoid nucleus (RTN) are part of the ventral respiratory component (VRC) in the central pattern respiratory generator (CPG), 
and are in contact with rythmogenic (pre-Bötzinger complex) and pre-motor neurons (Smith et al., 2013). The RTN receives inputs from NTS second-order neurons in contact with peripheral chemosensitive afferents, and seems to be responsible for the production of the reflex increase in ventilation (Takakura et al., 2006). In addition to the RTN, neurons in the $\mathrm{DMH}$ seem to facilitate and/or participate, at least in part, to the increase in frequency respiratory chemoreflex response (Kinkead et al., 2005; Silva et al., 2015) (Fig 13). Some studies investigating the effects of total disinhibition of neurons within the $\mathrm{DMH}$ (activation of the defense reaction) concluded that this procedure induces an increase in respiratory rate (McDowall et al., 2007; Reynolds et al., 2008). In this respect, the region of the DMH and the closely related perifornical area (PeF), are essential for generation of respiratory (tachypnea) responses to both stressful and alerting stimuli (Bondarenko et al., 2015). A hypothalamo-ponto-medullary pathway (HPM) seems to be involved in this response (Fig 13). Kölliker-Fuse and the lateral parabrachial nuclei receive projections from the DMH (Johnson et al., 2012; Peyron et al., 1998; Yokota et al., 2016) and form the pontine respiratory group, the activation of which evokes tachypneic or apneic responses (Chamberlin and Saper, 1994) through efferents to the VRC, including the RTN (Feldman et al., 2003; Smith et al., 2013).

On the other hand, the $\mathrm{DMH}$ is also involved in the production of long-term bradypnea after social defeat (Brouillard et al., 2016). Considering that a reduction in chemoreflex tachypneic response induces a long-term hypoventilation (Hayward, 2001; Roux et al., 2000), we hypothesised that $\mathrm{DMH}$ may exert a long-term negative influence on the peripheral chemoreflex to reduce baseline respiratory values after stress condition. Accordingly, we previously showed that mild DMH activation reduces the tachypnea (but not the increase in $V_{T}$ ) induced by KCN administration in male rats (Zafar et al., 2015).To note, . As the dIPAG intervenes downstream of the DMH to block the baroreflex cardiac response (Sévoz-Couche et al., 2003), we also hypothesised that dIPAG may be a relay in the DMHinduced negative effect on KCN-induced tachypnea (Lopes et al., 2014). Accordingly, chemical blockade of the dIPAG by muscimol in urethane-anesthetised rats prevented the negative modulation of the $\mathrm{KCN}$-induced increase in RF exerted by DMH low activation. Our findings show that electrical and chemical minimal sub-threshold dIPAG activation almost completely abolished the $\mathrm{KCN}$-induced increase in RF (but not the increase in $\mathrm{V}_{\mathrm{T}}$ ). 
Cardiovascular modifications induced by KCN were not analysed during mild DMH or dIPAG stimulation because higher intensity of stimulation is necessary to produce an effect on these responses (Netzer et al., 2009).

Social defeat induces long-term bradypnea via NTS $5-\mathrm{HT}_{3}$ receptor activation (Brouillard et al., 2016). This suggests that these receptors may play a crucial role in the inhibition of the chemoreflex tachypnea. In the present study, we showed that granisetron blocked the dIPAG-induced negative effect on chemoreflex tachypnea in rats. In addition, specific activation of NTS $5-\mathrm{HT}_{3}$ receptors by CPBG blocked the tachypnea induced by $\mathrm{KCN}$ administration in a dose-dependent manner. Moreover, this inhibitory effect of CPBG was prevented by a specific antagonist, granisetron. To confirm the key role of these receptors in the dIPAG inhibitory effect, we used genetically modified mice lacking $5-\mathrm{HT}_{3 a}$ receptors. To our knowledge, there is no published report on ventilation in $5-\mathrm{HT}_{3} \mathrm{a}$ KO mice. Both WT and $5-\mathrm{HT}_{3 a} \mathrm{KO}$ mice exhibited a significant lower $\mathrm{V}_{\mathrm{T}}$ than rats. The respiratory rate was higher in mice, albeit not significantly. WT and $5-\mathrm{HT}_{3 a} \mathrm{KO}$ mice had similar basal respiratory parameters, and KCN responses did not differ during baseline conditions. Inhibition of KCNinduced change in RF in $\mathrm{WT}$, but not $5-\mathrm{HT}_{3} \mathrm{KO}$ mice, was triggered by mild dIPAG activation. These results demonstrate that $5-\mathrm{HT}_{3}$ receptors are involved in dIPAG-induced reduction of $\mathrm{KCN}$-induced respiratory responses, but are not not tonically activated.

To explain these results, we propose the following neuronal pathway: during stress involving the $\mathrm{DMH}$, two clusters of neurons ( $\mathrm{A}$ and $\mathrm{B}$, see Fig 13 ) are activated in the $\mathrm{DMH}$. The cluster $A$ is at the origin of the HPM circuit, responsible for the defense and alerting tachypnea. On the other hand, the cluster B is a the origin of a hypothalamo-midbrainmedullary (HMM) pathway. Stimulation of the cluster B may activate the dIPAG. Direct projections have not been evidenced; the cuneiformis nucleus may be involved as an intermediary structure as it is reciprocally connected to both structures (Bernard et al., 2008). The $B 3$ region, and in particular the raphe magnus, receives massive projections from the dIPAG (Fardin et al., 1984) that, in turn, provides a significant set of serotonergic projection to the NTS (Schaffar et al., 1988; Thor and Helke, 1987). Thus dIPAG activation may be at the origin of serotonin release into the NTS, to ultimately activate presynaptic 5$\mathrm{HT}_{\text {за }}$ receptors (Hosford et al., 2014), as found previously (Bernard et al., 2008). The 
activation of these receptors is at the origin of vagal presynaptic glutamatergic release into the NTS (Ashworth-Preece et al., 1995), and glutamate acts on GABAergic interneurones embedded with excitatory amino acid receptors (Callera et al., 1997; Sévoz et al., 1996). In turn, GABA inhibits second-order carotid chemoreflex neurons through activation of $\mathrm{GABA}_{\mathrm{A}}$ receptors, and may block tachypneic chemoreflex responses as it was found previously for bradycardic chemoreflex responses in awake and anesthetized rats ( Sévoz et al., 1997). We hypothetized that, during stress, not only the HPM influence occurs to increase respiration, but the HMM pathway is activated to trigger a reduction in the chemoreflex RF produced from NTS second-order neurons by direct or indirect (activation of the HPM circuit) RTN cell activation. This inhibitory effect of the DMH and dIPAG is observed only under low electrical and chemical activation. It may depend on a functional subset of neurons in the DMH that is: i) sensitive to low depolarisation, or ii) smaller than that responsible for the pathway at the origin of the defense tachypnea (Fig 13). To our point of view, the HMM inputs may contain increases in RF if the peripheral chemoreflex occurs punctually while an anxious state is already present, to avoid panick attacks for exemple.

\section{Conclusion and Clinical significance}

This study shows that $\mathrm{DMH}$ reduction of the tachypneic response to peripheral chemoreflex activation involves dIPAG and NTS 5- $\mathrm{HT}_{3 a}$ receptor activation.

Failure to respond to hypoxia has been associated with early disturbances of respiratory control, including sudden infant death syndrome (SIDS) (Arata et al., 2013; McCulloch et al., 1982). In particular, decreased excitatory inputs from the peripheral arterial chemoreceptors to the second-order NTS neurons, result in reduced central drive to the muscles of respiration, predisposing to upper airway collapse during sleep (Gauda et al., 2007). A deficit in central chemoreception is commonly described in congenital central hypoventilation syndrome (CCHS) by a lack of Phox2B chemosensitive cells in the RTN (Bayliss et al., 2015; Guyenet et al., 2008). If it is generally accepted that CCHS patients have intact ventilatory responses to abrupt hypoxia, hypercapnia and hyperoxic challenges, indicating that peripheral chemoreceptor function is preserved in those who are able to sustain adequate ventilation during wakefulness (Gozal et al., 1993), some studies suggest that peripheral chemoreception may be affected for those who are not (Paton et al., 1989; Shea 1993). A dysfunctional peripheral chemoreception in CCHS was also mentioned by Shea 
and collaborators (Shea et al., 1993). A pivotal role for NTS 5-HT 3 a receptors in the DMHinduced reduction of vagal activity was evidenced earlier (Sévoz-Couche et al., 2003).

As SIDS and CCHS patients have a low vagal activity (Trang et al., 2005; White et al., 1993) and a reduced peripheral chemoreception, we suggest that the HMB neurocircuitry and especially NTS $5-\mathrm{HT}_{3}$ receptors may be a new target to prevent possible negative ventilatory and vagal outcomes in sub-groups of SIDS or CCHS.

\section{Author contributions}

The experimental team of Unit 1158 is involved in the automatic control of respiration. Caroline Sévoz-Couche is the principal coordinator of the projects on the modulatry effects of stress on reflex-induced modifications of respiration, and this study is part of these projects. Tabinda Zafar and Charly Brouillard performed the experiments, and Laurence Lanfumey is responsible for the mice breeding.

\section{Acknowledgement}

We would like to thank Brigitte Quenet for critical reading of the manuscript. This work was supported by Legs Poix (LEG1406). 
References

Abelson, J.L., Khan, S., and Giardino, N. (2010). HPA axis, respiration and the airways in stress--a review in search of intersections. Biol. Psychol. 84, 57-65.

Arata, S., Nakamachi, T., Onimaru, H., Hashimoto, H., and Shioda, S. (2013). Impaired response to hypoxia in the respiratory center is a major cause of neonatal death of the PACAP-knockout mouse. Eur. J. Neurosci. 37, 407-416.

Ashworth-Preece, M.A., Jarrott, B., and Lawrence, A.J. (1995). 5-Hydroxytryptamine3 receptor modulation of excitatory amino acid release in the rat nucleus tractus solitarius. Neurosci. Lett. 191, 75-78.

Bandler, R., and Carrive, P. (1988). Integrated defence reaction elicited by excitatory amino acid microinjection in the midbrain periaqueductal grey region of the unrestrained cat. Brain Res. 439, 95-106.

Bandler, R., Keay, K.A., Floyd, N., and Price, J. (2000). Central circuits mediating patterned autonomic activity during active vs. passive emotional coping. Brain Res. Bull. 53, 95-104.

Bayliss, D.A., Barhanin, J., Gestreau, C., and Guyenet, P.G. (2015). The role of pH-sensitive TASK channels in central respiratory chemoreception. Pflugers Arch. 467, 917-929.

Bernard, J.-F., Netzer, F., Gau, R., Hamon, M., Laguzzi, R., and Sévoz-Couche, C. (2008). Critical role of $\mathrm{B} 3$ serotonergic cells in baroreflex inhibition during the defense reaction triggered by dorsal periaqueductal gray stimulation. J. Comp. Neurol. 506, 108-121.

Bondarenko, E., Beig, M.I., Hodgson, D.M., Braga, V.A., and Nalivaiko, E. (2015). Blockade of the dorsomedial hypothalamus and the perifornical area inhibits respiratory responses to arousing and stressful stimuli. Am. J. Physiol. Regul. Integr. Comp. Physiol. 308, R816-822.

Brouillard, C., Carrive, P., Camus, F., Benoliel, J.-J., Similowski, T., and Sévoz-Couche, C. (2016). Long-lasting bradypnea induced by repeated social defeat. Am. J. Physiol. Regul. Integr. Comp. Physiol. ajpregu.00021.2016.

Callera, J.C., Bonagamba, L.G., Sévoz, C., Laguzzi, R., and Machado, B.H. (1997). Cardiovascular effects of microinjection of low doses of serotonin into the NTS of unanesthetized rats. Am. J. Physiol. 272, R1135-1142.

Carnevali, L., Sgoifo, A., Trombini, M., Landgraf, R., Neumann, I.D., and Nalivaiko, E. (2013). Different patterns of respiration in rat lines selectively bred for high or low anxiety. PloS One 8, e64519.

Chamberlin, N.L., and Saper, C.B. (1994). Topographic organization of respiratory responses to glutamate microstimulation of the parabrachial nucleus in the rat. J. Neurosci. Off. J. Soc. Neurosci. 14, 6500-6510. 
Comet, M.-A., Sévoz-Couche, C., Hanoun, N., Hamon, M., and Laguzzi, R. (2004). 5-HTmediated inhibition of cardiovagal baroreceptor reflex response during defense reaction in the rat. Am. J. Physiol. Heart Circ. Physiol. 287, H1641-1649.

Comet, M.-A., Bernard, J.F., Hamon, M., Laguzzi, R., and Sévoz-Couche, C. (2007). Activation of nucleus tractus solitarius 5-HT2A but not other 5-HT2 receptor subtypes inhibits the sympathetic activity in rats. Eur. J. Neurosci. 26, 345-354.

Damasceno, R.S., Takakura, A.C., and Moreira, T.S. (2015). Respiratory and sympathetic chemoreflex regulation by Kölliker-Fuse neurons in rats. Pflugers Arch. 467, 231-239.

Fardin, V., Oliveras, J.L., and Besson, J.M. (1984). Projections from the periaqueductal gray matter to the B3 cellular area (nucleus raphe magnus and nucleus reticularis paragigantocellularis) as revealed by the retrograde transport of horseradish peroxidase in the rat. J. Comp. Neurol. 223, 483-500.

Feldman, J.L., Mitchell, G.S., and Nattie, E.E. (2003). Breathing: rhythmicity, plasticity, chemosensitivity. Annu. Rev. Neurosci. 26, 239-266.

Gauda, E.B., Cristofalo, E., and Nunez, J. (2007). Peripheral arterial chemoreceptors and sudden infant death syndrome. Respir. Physiol. Neurobiol. 157, 162-170.

Gonzalez, F., Fordyce, W.E., and Grodins, F.S. (1977). Mechanism of respiratory responses to intravenous NaHCO3, HCl, and KCN. J. Appl. Physiol. 43, 1075-1079.

Gozal, D., Marcus, C.L., Shoseyov, D., and Keens, T.G. (1993). Peripheral chemoreceptor function in children with the congenital central hypoventilation syndrome. J. Appl. Physiol. Bethesda Md 1985 74, 379-387.

Guyenet, P.G., Stornetta, R.L., and Bayliss, D.A. (2008). Retrotrapezoid nucleus and central chemoreception. J. Physiol. 586, 2043-2048.

Hayward, L.F. (2001). Evidence for alpha-2 adrenoreceptor modulation of arterial chemoreflexes in the caudal solitary nucleus of the rat. Am. J. Physiol. Regul. Integr. Comp. Physiol. 281, R1464-1473.

Hayward, L.F., and Castellanos, M. (2003). Increased c-Fos expression in select lateral parabrachial subnuclei following chemical versus electrical stimulation of the dorsal periaqueductal gray in rats. Brain Res. 974, 153-166.

Hosford, P.S., Mifflin, S.W., and Ramage, A.G. (2014). 5-hydroxytryptamine-mediated neurotransmission modulates spontaneous and vagal-evoked glutamate release in the nucleus of the solitary tract effect of uptake blockade. J. Pharmacol. Exp. Ther. 349, 288296.

Isom, G.E., Burrows, G.E., and Way, J.L. (1982). Effect of oxygen on the antagonism of cyanide intoxication--cytochrome oxidase, in vivo. Toxicol. Appl. Pharmacol. 65, 250-256. 
Izumizaki, M., Pokorski, M., and Homma, I. (2004). Role of the carotid bodies in chemosensory ventilatory responses in the anesthetized mouse. J. Appl. Physiol. Bethesda Md 1985 97, 1401-1407.

Johnson, P.L., Truitt, W.A., Fitz, S.D., Lowry, C.A., and Shekhar, A. (2008). Neural pathways underlying lactate-induced panic. Neuropsychopharmacol. Off. Publ. Am. Coll.

Neuropsychopharmacol. 33, 2093-2107.

Johnson, P.L., Molosh, A., Fitz, S.D., Truitt, W.A., and Shekhar, A. (2012). Orexin, stress, and anxiety/panic states. Prog. Brain Res. 198, 133-161.

Kinkead, R., Gulemetova, R., and Bairam, A. (2005). Neonatal maternal separation enhances phrenic responses to hypoxia and carotid sinus nerve stimulation in the adult anesthetized rat. J. Appl. Physiol. Bethesda Md 1985 99, 189-196.

Kinkead, R., Montandon, G., Bairam, A., Lajeunesse, Y., and Horner, R. (2009). Neonatal maternal separation disrupts regulation of sleep and breathing in adult male rats. Sleep 32, 1611-1620.

Koshiya, N., and Guyenet, P.G. (1994). Role of the pons in the carotid sympathetic chemoreflex. Am. J. Physiol. 267, R508-518.

Krout, K.E., Jansen, A.S., and Loewy, A.D. (1998). Periaqueductal gray matter projection to the parabrachial nucleus in rat. J. Comp. Neurol. 401, 437-454.

Lopes, L.T., Biancardi, V., Vieira, E.B., Leite-Panissi, C., Bícego, K.C., and Gargaglioni, L.H. (2014). Participation of the dorsal periaqueductal grey matter in the hypoxic ventilatory response in unanaesthetized rats. Acta Physiol. Oxf. Engl. 211, 528-537.

McCulloch, K., Brouillette, R.T., Guzzetta, A.J., and Hunt, C.E. (1982). Arousal responses in near-miss sudden infant death syndrome and in normal infants. J. Pediatr. 101, 911-917.

McDowall, L.M., Horiuchi, J., and Dampney, R.A.L. (2007). Effects of disinhibition of neurons in the dorsomedial hypothalamus on central respiratory drive. Am. J. Physiol. Regul. Integr. Comp. Physiol. 293, R1728-1735.

Netzer, F., Mandjee, N., Verberne, A.J., Bernard, J.-F., Hamon, M., Laguzzi, R., and SévozCouche, C. (2009). Inhibition of the bradycardic component of the von Bezold-Jarisch reflex and carotid chemoreceptor reflex by periaqueductal gray stimulation: involvement of medullary receptors. Eur. J. Neurosci. 29, 2017-2028.

Netzer, F., Bernard, J.-F., Verberne, A.J.M., Hamon, M., Camus, F., Benoliel, J.-J., and SévozCouche, C. (2011). Brain circuits mediating baroreflex bradycardia inhibition in rats: an anatomical and functional link between the cuneiform nucleus and the periaqueductal grey. J. Physiol. 589, 2079-2091.

Olson, E.B., Vidruk, E.H., and Dempsey, J.A. (1988). Carotid body excision significantly changes ventilatory control in awake rats. J. Appl. Physiol. Bethesda Md 1985 64, 666-671. 
Paton, J.Y., Swaminathan, S., Sargent, C.W., and Keens, T.G. (1989). Hypoxic and hypercapnic ventilatory responses in awake children with congenital central hypoventilation syndrome. Am. Rev. Respir. Dis. 140, 368-372.

Peyron, C., Tighe, D.K., van den Pol, A.N., de Lecea, L., Heller, H.C., Sutcliffe, J.G., and Kilduff, T.S. (1998). Neurons containing hypocretin (orexin) project to multiple neuronal systems. J. Neurosci. Off. J. Soc. Neurosci. 18, 9996-10015.

Purves, M.J. (1966). The effects of hypoxia in the new-born lamb before and after denervation of the carotid chemoreceptors. J. Physiol. 185, 60-77.

Reynolds, C.R., Vujisic, K., Davenport, P.W., and Hayward, L.F. (2008). Disinhibition of the dorsomedial hypothalamus increases the frequency of augmented breaths in the anesthetized rat. Adv. Exp. Med. Biol. 605, 274-278.

Roux, J.C., Peyronnet, J., Pascual, O., Dalmaz, Y., and Pequignot, J.M. (2000). Ventilatory and central neurochemical reorganisation of $\mathrm{O} 2$ chemoreflex after carotid sinus nerve transection in rat. J. Physiol. 522 Pt 3, 493-501.

Schaffar, N., Kessler, J.P., Bosler, O., and Jean, A. (1988). Central serotonergic projections to the nucleus tractus solitarii: evidence from a double labeling study in the rat. Neuroscience 26, 951-958.

Sévoz, C., Hamon, M., and Laguzzi, R. (1996). Medullary pathways of cardiovascular responses to $5-\mathrm{HT} 2$ and $5-\mathrm{HT} 3$ receptor stimulation in the rat nucleus tractus solitarius. Neuroreport 7, 1965-1969.

Sévoz, C., Callera, J.C., Machado, B.H., Hamon, M., and Laguzzi, R. (1997). Role of serotonin3 receptors in the nucleus tractus solitarii on the carotid chemoreflex. Am. J. Physiol. 272, H1250-1259.

Sévoz-Couche, C., Nosjean, A., Franc, B., Hamon, M., and Laguzzi, R. (1998). Dorsal medullary 5-HT3 receptors and sympathetic premotor neurones in the rat. J. Physiol. 508 ( Pt 3), 747762.

Sévoz-Couche, C., Comet, M.-A., Hamon, M., and Laguzzi, R. (2003). Role of nucleus tractus solitarius 5-HT3 receptors in the defense reaction-induced inhibition of the aortic baroreflex in rats. J. Neurophysiol. 90, 2521-2530.

Shea, S.A., Andres, L.P., Shannon, D.C., and Banzett, R.B. (1993). Ventilatory responses to exercise in humans lacking ventilatory chemosensitivity. J. Physiol. 468, 623-640.

Silva, N.T., Nalivaiko, E., da Silva, L.G., and Haibara, A.S. (2015). Excitatory amino acid receptors in the dorsomedial hypothalamic area contribute to the chemoreflex tachypneic response. Respir. Physiol. Neurobiol. 212-214, 1-8.

Smith, J.C., Abdala, A.P.L., Borgmann, A., Rybak, I.A., and Paton, J.F.R. (2013). Brainstem respiratory networks: building blocks and microcircuits. Trends Neurosci. 36, 152-162. 
Smith, O.A., DeVito, J.L., and Astley, C.A. (1990). Neurons controlling cardiovascular responses to emotion are located in lateral hypothalamus-perifornical region. Am. J. Physiol. 259, R943-954.

Song, G., Xu, H., Wang, H., Macdonald, S.M., and Poon, C.-S. (2011). Hypoxia-excited neurons in NTS send axonal projections to Kölliker-Fuse/parabrachial complex in dorsolateral pons. Neuroscience 175, 145-153.

Takakura, A.C.T., Moreira, T.S., Colombari, E., West, G.H., Stornetta, R.L., and Guyenet, P.G. (2006). Peripheral chemoreceptor inputs to retrotrapezoid nucleus (RTN) CO2-sensitive neurons in rats. J. Physiol. 572, 503-523.

Thor, K.B., and Helke, C.J. (1987). Serotonin- and substance P-containing projections to the nucleus tractus solitarii of the rat. J. Comp. Neurol. 265, 275-293.

Trang, H., Girard, A., Laude, D., and Elghozi, J.-L. (2005). Short-term blood pressure and heart rate variability in congenital central hypoventilation syndrome (Ondine's curse). Clin. Sci. Lond. Engl. 1979 108, 225-230.

White, M., Beckett, M., O'Regan, M., and Matthews, T. (1993). Autonomic function and SIDS. Acta Paediatr. Oslo Nor. 1992 Suppl. 82 Suppl 389, 105-106.

Yokota, S., Oka, T., Asano, H., and Yasui, Y. (2016). Orexinergic fibers are in contact with Kölliker-Fuse nucleus neurons projecting to the respiration-related nuclei in the medulla oblongata and spinal cord of the rat. Brain Res. 1648, 512-523.

Zafar, T., Brouillard, C., and Sévoz-Couche, C. (2015). Respiratory chemoreflex response inhibition by dorsomedian hypothalamic nucleus activation in rats. Respir. Physiol. Neurobiol.

Zaretskaia, M.V., Zaretsky, D.V., Sarkar, S., Shekhar, A., and DiMicco, J.A. (2008). Induction of Fos-immunoreactivity in the rat brain following disinhibition of the dorsomedial hypothalamus. Brain Res. 1200, 39-50.

Zeitz, K.P., Guy, N., Malmberg, A.B., Dirajlal, S., Martin, W.J., Sun, L., Bonhaus, D.W., Stucky, C.L., Julius, D., and Basbaum, A.I. (2002). The 5-HT3 subtype of serotonin receptor contributes to nociceptive processing via a novel subset of myelinated and unmyelinated nociceptors. J. Neurosci. Off. J. Soc. Neurosci. 22, 1010-1019. 


\section{Figure legends}

\section{Figure 1.}

Experimental design used to evaluate the role of the dIPAG (Experiments 1 and 2) on DMHinduced negative influence on $\mathrm{KCN}$ respiratory responses.

Elec: electrical activation; Bic: bicuculline; Musc: muscimol

\section{Figure 2.}

Experimental design used to evaluate the role of the NTS 5- $\mathrm{HT}_{3 a}$ receptor on dIPAG-induced negative influence on $\mathrm{KCN}$ respiratory responses (Experiments 3 to 5).

CPBG: m-chlorophenybiguanide; Grani: granisetron

Figure 3.

A and B. Box-Whisker graphs with min and max values (lines are the medians), showing the effect of intra-dIPAG vehicle (veh) or muscimol (musc) on the reduction of $K C N$-induced $\triangle \mathrm{RF}$ and $\Delta \mathrm{V}_{\mathrm{T}}$, exerted by $\mathrm{DMH}$ electrical $(\mathrm{A})$ and chemical $(\mathrm{B})$ activation. Values are means \pm sem. $* * p<0.01$ versus Sham $D M H, \# \# p<0.01$ and $\# \# \# p<0.001$ versus intra-dIPAG veh.

Figure 4.

Representative traces of respiratory responses induced by $\mathrm{KCN}$ administration (arrows) at baseline (i.e. during sham $\mathrm{DMH}$, top) and during low chemical $\mathrm{DMH}$ activation (middle) by bicuculline $(0.05 \mathrm{mM})$; the $\mathrm{DMH}$-induced inhibitory effect on chemoreflex tachypnea was reversed by dIPAG blockade with bicuculline $(5 \mathrm{mM})$. HR: heart rate, ABP: differential arterial blood pressure.

Figure 5.

Photographs displaying the dIPAG (A) and NTS (B) sites (pontamine sky blue deposit at the very tip of the micropipette track, marked by the asterisks), at approximately $-6.8 \mathrm{~mm}$ and $14.2 \mathrm{~mm}$ from bregma, respectively.

$3 \mathrm{~N}$ : occulomotor nucleus; $10 \mathrm{~N}$ : dorsal motor nucleus of vagus; $12 \mathrm{~N}$ : hypoglossal nucleus; AP: area postrema; cc: central canal; CuR: cuneate nucleus (rotandus part); dIPAG: dorsolateral 
column of the periaqueductal gray area;dmPAG: dorsomedial column of the periaqueductal gray area; Gr: gracile nucleus; IPAG: lateral column of the periaqueductal gray area; Sol: nucleus of the solitary tract;

Figure 6.

A and B. Box-Whisker graphs with min and max values (lines are the medians), showing the effect of sham (no passing current) or experimental (exp, passing current) electrical (A), and sham (vehicle) or experimental (bicuculline) chemical (B) dIPAG activation, on KCN-induced changes in tracheal breath frequency $(\Delta R F)$ and tidal volume $\left(\Delta V_{T}\right)$. Values are means \pm sem. $* * * p<0.001$ versus sham.

Figure 7.

A and B. Box-Whisker graphs with min and max values (lines are the medians), showing the effect of intra-NTS vehicle (veh) or granisetron (grani) at the dose of 125 (A) and 250 pmol (B) on the reduction of $K C N$-induced $\triangle \mathrm{RF}$ and $\Delta \mathrm{V}_{\mathrm{T}}$, exerted by $\mathrm{DMH}$ electrical activation. Values are means \pm sem. ${ }^{* *} p<0.01$ and ${ }^{* * *} p<0.001$ versus Sham dIPAG, $\# p<0.01$ and $\# \# \#<0.001$ versus intra-NTS veh.

Figure 8.

Representative traces of respiratory responses induced by $\mathrm{KCN}$ administration (arrows) at baseline (i.e. during sham dIPAG, top) and during low electrical dIPAG activation (middle); the dIPAG-induced inhibitory effect on chemoreflex tachypnea was reversed by NTS $5-\mathrm{HT}_{3}$ receptor blockade with granisetron $(250 \mathrm{pmol})$.

Figure 9.

Box-Whisker graphs with min and max values (lines are the medians), showing the effect of sham (no passing current) or experimental (exp, passing current) dIPAG electrical activation on $\mathrm{KCN}$-induced changes in $\mathrm{RF}$ and $\mathrm{V}_{\mathrm{T}}$ in wild-type (WT, top) and 5- $\mathrm{HT}_{3 \mathrm{a}} \mathrm{KO}$ (bottom) mice. Values are means \pm sem. ${ }^{* *} p<0.01$ versus sham. 
Figure 10.

Representative responses of $\mathrm{RF}$ and $\mathrm{V}_{\mathrm{T}}$ to $\mathrm{KCN}$ administration (arrows) during sham (no passing current) or experimental (exp, passing current) dIPAG electrical stimulation, in WT (A) or $5-\mathrm{HT}_{3 \mathrm{a}} \mathrm{KO}(\mathrm{B})$ mice.

Figure 11.

Dose-dependent inhibition of peripheral chemoreflex tachypnea by various doses (0.1 to 1.6 nmol) of intra-NTS CPBG. Values are means \pm sem. ${ }^{*} p<0.05$ and ${ }^{*} p<0.01$ vs intra-NTS veh; $\# p<0.05$ versus lower dose.

Figure 12.

Representative responses of $\mathrm{RF}$ and $\mathrm{V}_{\mathrm{T}}$ to $\mathrm{KCN}$ administration (arrows), after intra-NTS vehicle (sham chemical stimulation) or CPBG $(0.4 \mathrm{nmol}$, experimental chemical stimulation).

Figure 13.

Hypothetical schematic representation of the neurocircuitry involved in respiratory modulation by the $\mathrm{DMH}$.

NTS second-order carotid chemoreflex neurons (grey cell) project to the DMH (Silva et al., 2015) and to the medullary ventral respiratory component (VRC), in particular to the retrotrapezoid nucleus (RTN) (Takakura et al., 2006). RTN neurons activate rythmogenic neurons (to increase RF) and pre-motor neurons (to increase the tidal volume) (Takakura et al., 2006).

Firstly, DMH neurons ("A") are associated with the pontine formation (Hayward and Castellanos, 2003; Johnson et al., 2008; Krout et al., 1998) which, in turn, is in contact with the RTN (Damasceno et al., 2015; Song et al., 2011). During alerting stimuli, this Hypothalamo-Ponto-Medullary or HPM circuit (grey pathway) induces the typical defense respiratory response (tachypnea and increase in tidal volume). This pathway may also participate, at least in part, to the peripheral chemoreflex ventilatory response by direct projections from the NTS to the DMH.

Secondarily, $\mathrm{DMH}$ "B" cells are projecting to the cuneiform nucleus ( $\mathrm{CnF}$ ) and their activation 
results in the stimulation dIPAG neurons. This circuit may be the origin of serotonin release into the NTS (presumably from the B3 region (Netzer et al., 2011)) to ultimately activate presynaptic $5-\mathrm{HT}_{3}$ receptors located pre-synaptically on vagal afferents (white pathway). Activation of these receptors induces the presynaptic release of glutamate that stimulates GABAergic interneurones (black cell). Finally, GABA acts on $\mathrm{GABA}_{A}$ receptors present on NTS second-order carotid chemoreflex neurons to block (black crosses) chemoreflex inputs to both DMH "A" and RTN cells. The activation of this Hypothalamo-Midbrain-Medularry circuit (HMM), ultimately reduces the chemoreflex respiratory response (black cross) presumably to prevent maximum RF levels during stress alert. Of note, RTN cells receiving chemoreflex inputs inhibited by the HMM circuit may be associated with rythmogenic cells, but not premotor cells in the VRC.

We suggest that during alerting stimuli, both HMM and HPM are activated in parallel; during a low stress state HMM alone is activated because only a low DMH activation occurs and may participate in the establishment of long-term stress-induced bradypnea. 


\section{Table 1}

Basal respiratory parameters in rats and mice

\begin{tabular}{|l|l|l|l|l|}
\hline & Basal RF (cpm) & Basal V $\mathbf{T}(\mathbf{m l})$ & Basal HR (bpm) & Basal ABP $(\mathbf{m m H g})$ \\
\hline Rat $(\mathbf{n = 7 6})$ & $109 \pm 4$ & $2.15 \pm 0.10$ & $355 \pm 10$ & $100 \pm 5$ \\
\hline wt (n=5) & $124 \pm 5$ & $0.70 \pm 0.10$ & $510 \pm 12$ & $90 \pm 7$ \\
\hline ko (n=5) & $127 \pm 11$ & $0.60 \pm 0.03$ & $540 \pm 15$ & $85 \pm 5$ \\
\hline
\end{tabular}

Values are the mean \pm sem

Table 2

Variations in RF and VT produced by microinjections in the rats of active substances in the DMH, dIPAG and NTS.

\begin{tabular}{|c|c|c|c|c|c|}
\hline Localisation & Treatment & $\Delta \mathrm{RF}$ (cpm) & $\Delta \mathrm{VT}(\mathrm{ml})$ & $\begin{array}{l}\Delta \mathrm{HR} \\
\text { (bpm) }\end{array}$ & $\begin{array}{l}\triangle \mathrm{ABP} \\
(\mathrm{mmHg})\end{array}$ \\
\hline \multirow[t]{2}{*}{$\mathrm{DMH}$} & Vehicle $(n=6)$ & $+4 \pm 2$ & $+0.1 \pm 0.2$ & $+6 \pm 2$ & $+4 \pm 2$ \\
\hline & Bicuculline $5 \mathrm{pmol}(\mathrm{n}=6)$ & $+4 \pm 3$ & $+0.4 \pm 0.2$ & $+15 \pm 8$ & $+8 \pm 5$ \\
\hline \multirow[t]{3}{*}{ dIPAG } & Vehicle $(n=6)$ & $+1 \pm 2$ & $+0.2 \pm 0.2$ & $+5 \pm 2$ & $+4 \pm 3$ \\
\hline & Bicuculline 5 pmol ( $n=19)$ & $+6 \pm 3$ & $+0.3 \pm 0.2$ & $+10 \pm 5$ & $+10 \pm 5$ \\
\hline & Muscimol $500 \mathrm{pmol}(\mathrm{n}=12)$ & $-1 \pm 3$ & $-0.4 \pm 0.2$ & $+7 \pm 5$ & $+5 \pm 5$ \\
\hline \multirow[t]{8}{*}{ NTS } & Vehicle $(n=36)$ & $+3 \pm 2$ & $+0.2 \pm 0.2$ & $+4 \pm 2$ & $+3 \pm 2$ \\
\hline & Granisetron $125 \mathrm{pmol}(\mathrm{n}=6)$ & $+5 \pm 2$ & $+0.2 \pm 0.1$ & $+5 \pm 4$ & $+8 \pm 5$ \\
\hline & Granisetron $250 \mathrm{pmol}(\mathrm{n}=11)$ & $+6 \pm 3$ & $+0.3 \pm 0.1$ & $+5 \pm 8$ & $+8 \pm 5$ \\
\hline & CPBG $0.1 \mathrm{nmol}(\mathrm{n}=5)$ & $+3 \pm 2$ & $+0.2 \pm 0.1$ & $+8 \pm 2$ & $+8 \pm 2$ \\
\hline & CPBG $0.2 \mathrm{nmol}(\mathrm{n}=5)$ & $+4 \pm 3$ & $+0.4 \pm 0.1$ & $+5 \pm 5$ & $+9 \pm 3$ \\
\hline & CPBG $0.4 \mathrm{nmol}(n=5)$ & $-3 \pm 3$ & $+0.5 \pm 0.1$ & $+10 \pm 8$ & $+10 \pm 5$ \\
\hline & CPBG $0.8 \mathrm{nmol}(\mathrm{n}=10)$ & $-6 \pm 2$ & $+0.5 \pm 0.1$ & $+12 \pm 5$ & $+21 \pm 5$ \\
\hline & CPBG $1.6 \mathrm{nmol}(\mathrm{n}=5)$ & $-5 \pm 3$ & $+0.4 \pm 0.3$ & $+5 \pm 4$ & $+28 \pm 6$ \\
\hline
\end{tabular}

Values are the mean \pm sem in $\mathbf{n}$ animals 
A

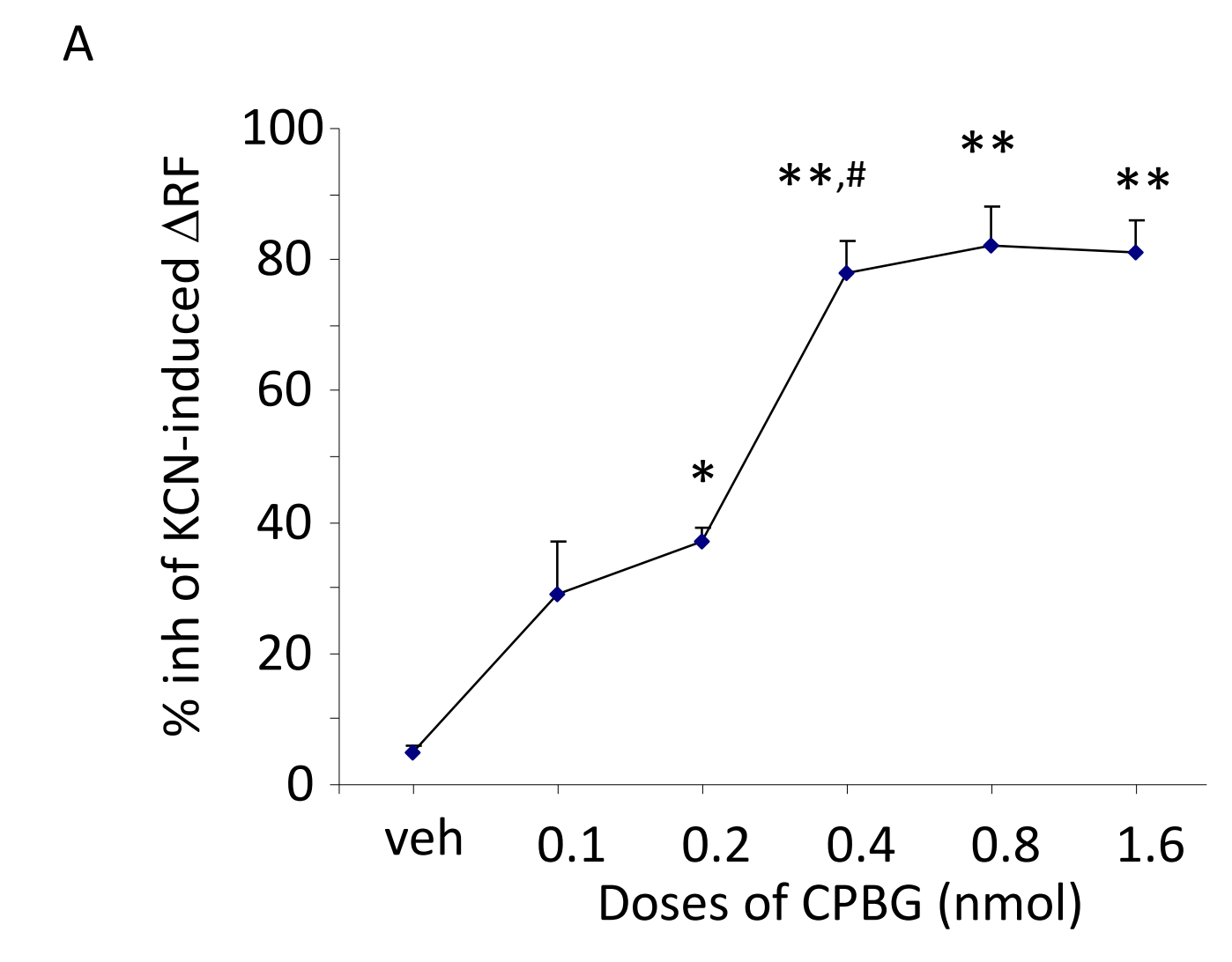

Experiment 5

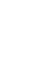

(1)

(1) (1)

\title{
experiment
} (1)

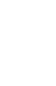

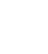

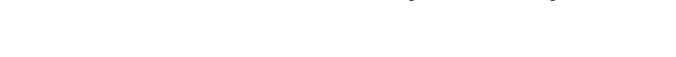

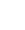

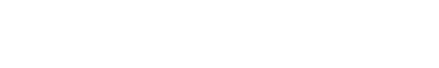




\section{After intra-NTS vehicle}

$\mathrm{RF}(\mathrm{cpm})$

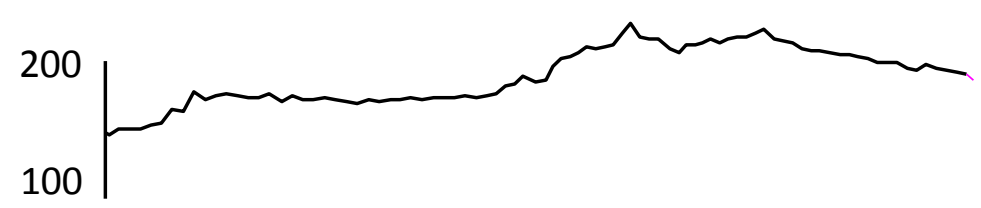

Flow

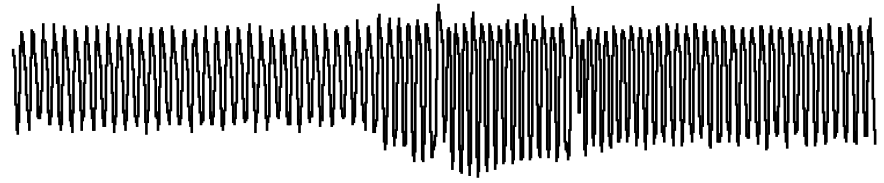

HR (bpm)

500
250

$\mathrm{ABP}(\mathrm{mmHg})$

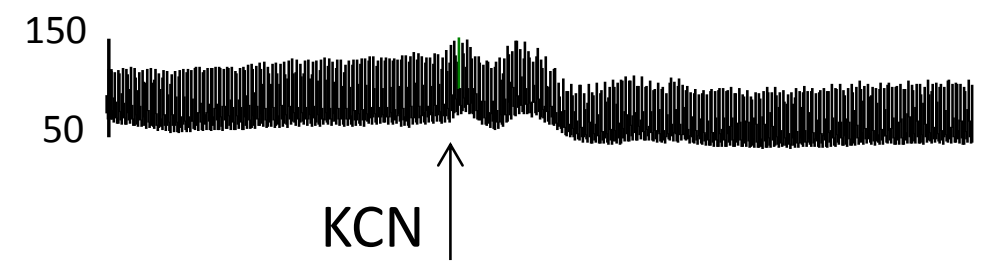

After intra-NTS CPBG (0.4 nmol)

$\mathrm{RF}(\mathrm{cpm})$

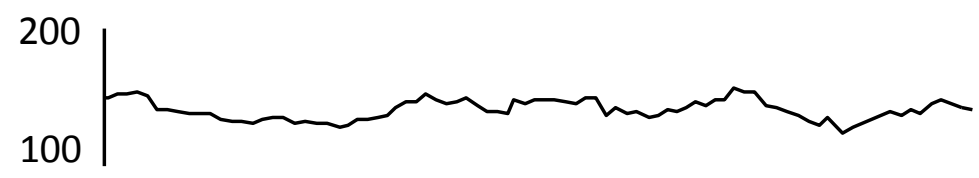

Flow

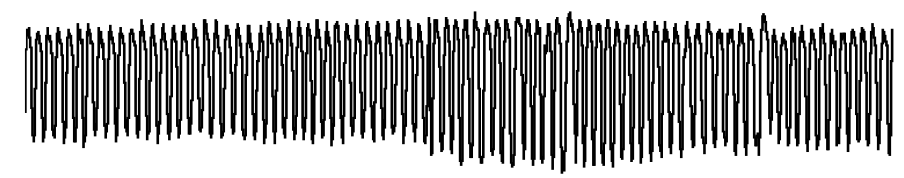

HR (bpm)

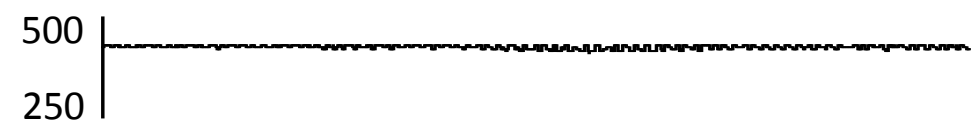

$\mathrm{ABP}(\mathrm{mmHg})$

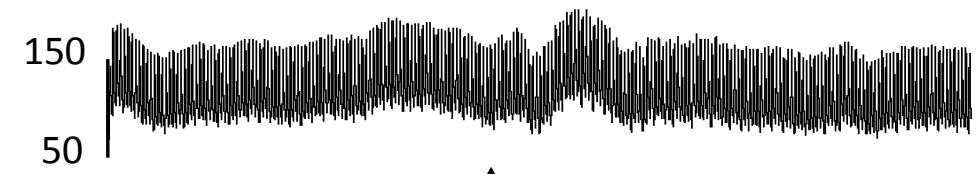

KCN $\uparrow$ 
Hypothalamus

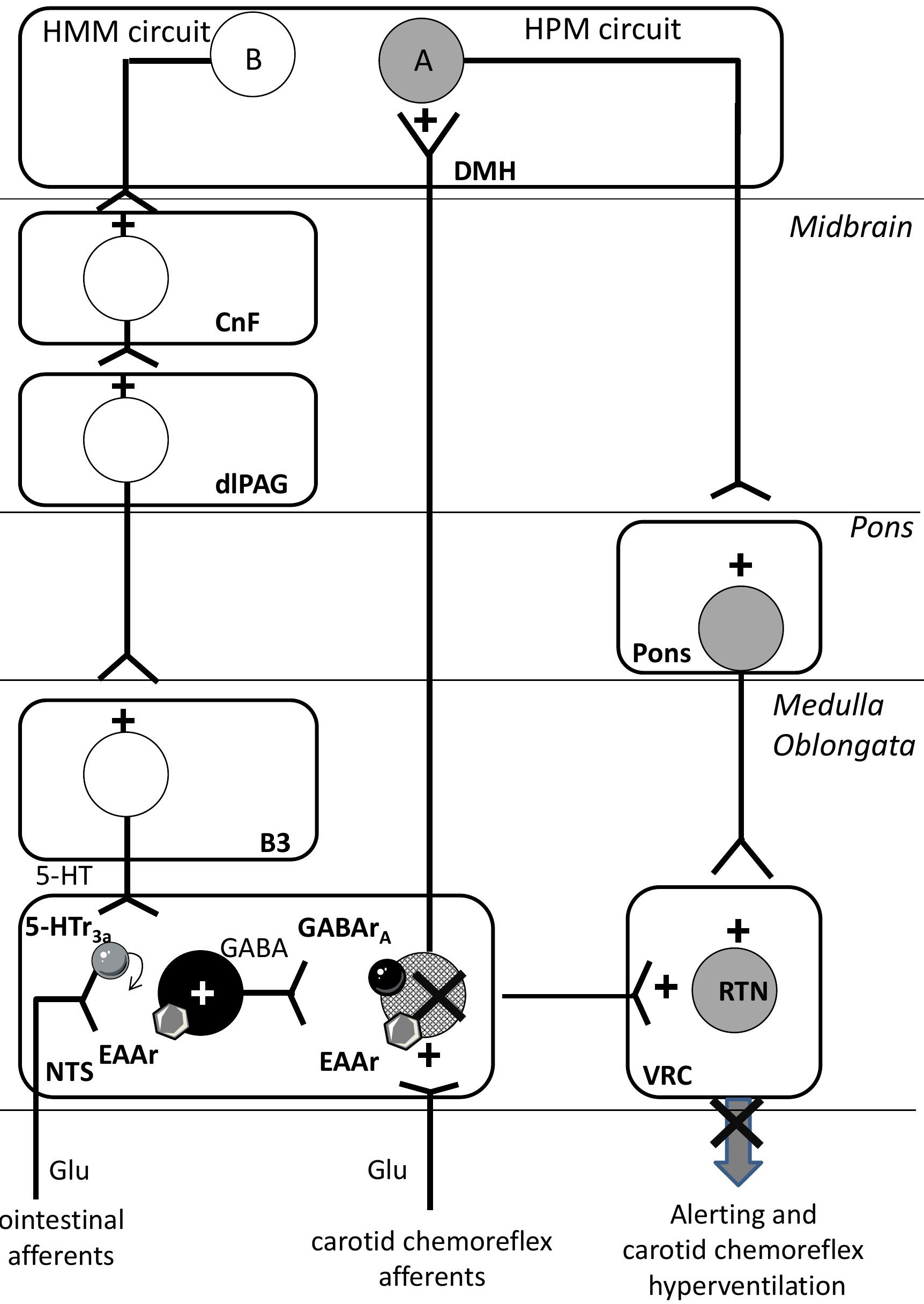


-Experiment 1: Does dIPAG blockade reverse the inhibitory action of low electrical (A) and chemical (B) stimulation of the $\mathrm{DMH}$ on $\mathrm{KCN}$-induced respiratory responses in rats?
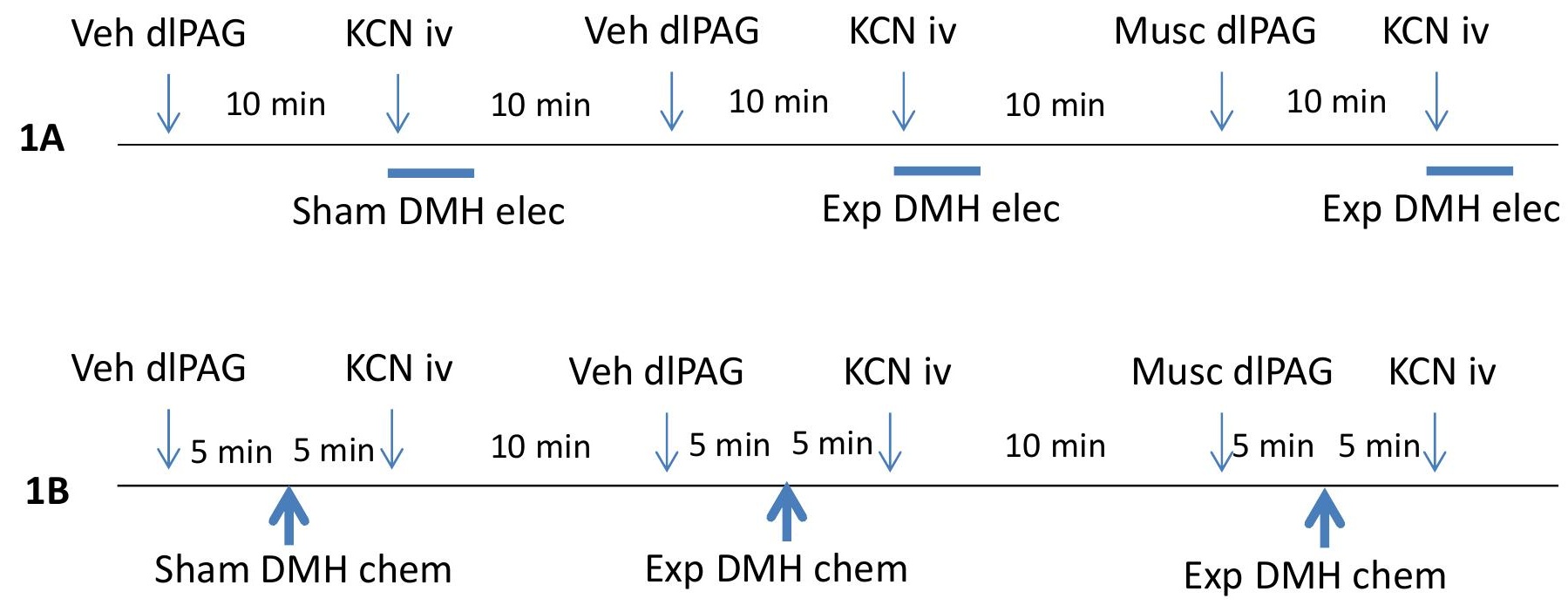

-Experiment 2: Does low electrical (A) or chemical (B) dIPAG stimulation exert an inhibito action on $\mathrm{KCN}$-induced respiratory responses in rats?

$\mathrm{KCN}$ iv

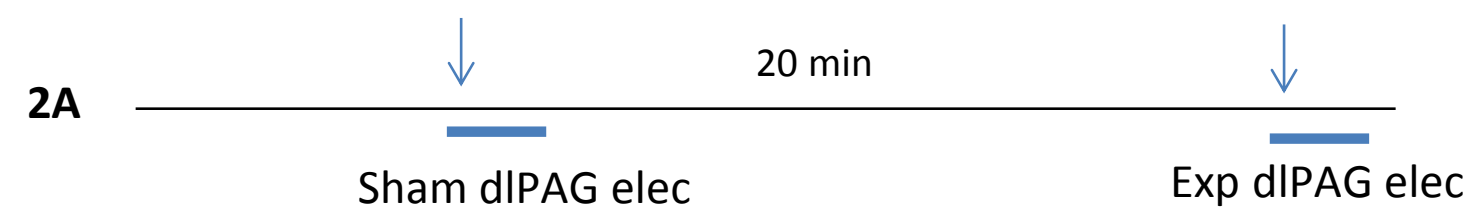

$\mathrm{KCN}$ iv

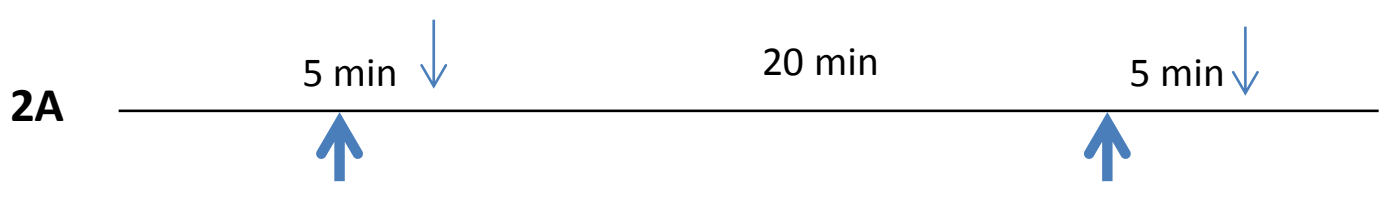

Sham dIPAG chem
Exp dIPAG chem 
-Experiment 3: Does NTS 5- $\mathrm{HT}_{3}$ receptor inhibition reverse the negative influence exerted by low electrical stimulation of the dIPAG on KCN-induced respiratory responses in rats?

\begin{tabular}{|c|c|c|c|c|c|c|}
\hline Veh NTS & $\mathrm{KCN}$ iv & Veh NTS & $\mathrm{KCN}$ iv & & grani NTS & $\mathrm{KCN}$ iv \\
\hline$\downarrow 10 \mathrm{~min}$ & $\downarrow \quad 10 \mathrm{~min}$ & $\downarrow 10 \mathrm{~min}$ & $\downarrow$ & $10 \mathrm{~min}$ & $\downarrow 10 \mathrm{~min}$ & $\downarrow$ \\
\hline
\end{tabular}

-Experiment 4: Does the 5- $\mathrm{HT}_{3 \mathrm{a}}$ receptor exert a role in the effects of low electrical activation of the dIPAG on KCN-induced respiratory responses in WT (A) and $5-\mathrm{HT}_{3 \mathrm{a}} \mathrm{KO}$ (B) mice?

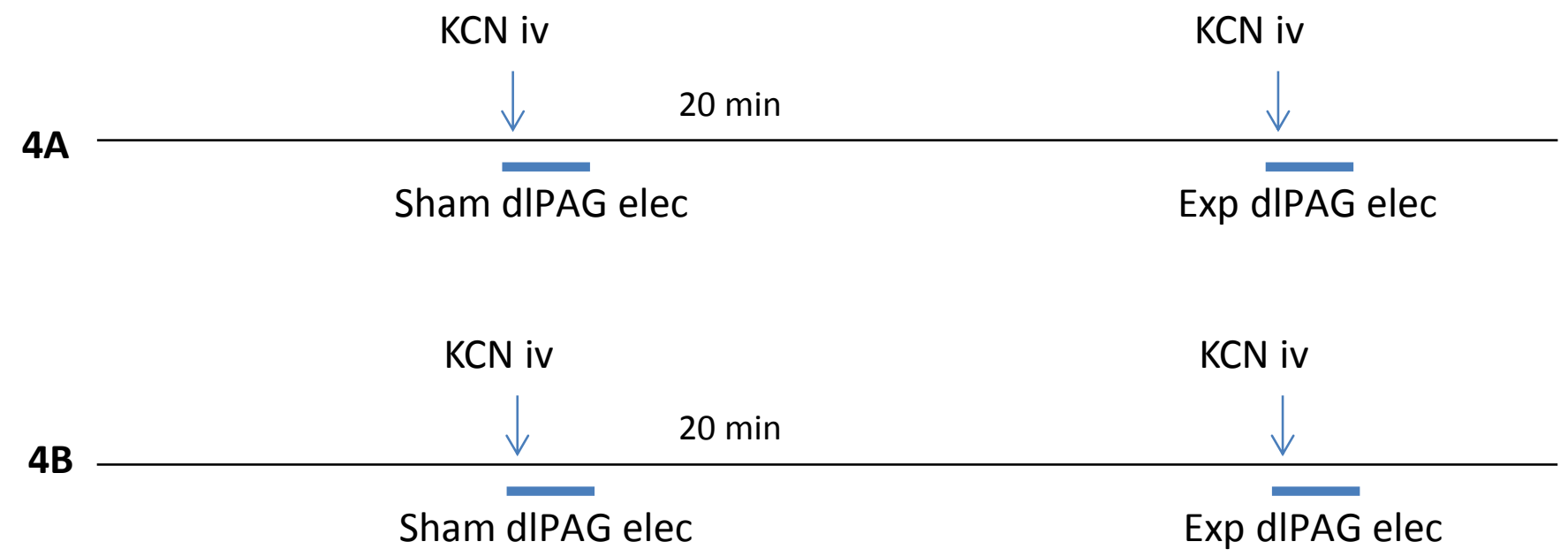

-Experiment 5: Does NTS 5- $\mathrm{HT}_{3}$ receptor activation exert an inhibitory effect on $\mathrm{KCN}$ induced respiratory responses $(A)$, and can this inhibitory effect be prevented by prior injection of granisetron (B)?
Veh NTS KCN iv
CPBG NTS KCN iv

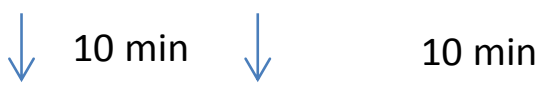
$\downarrow 10 \mathrm{~min} \downarrow$

$5 A$

Veh NTS KCN iv grani NTS CPBG NTS KCN iv

$\downarrow 10 \mathrm{~min} \downarrow \quad 8 \mathrm{~min} \quad \downarrow 2 \mathrm{~min} \quad \downarrow 10 \mathrm{~min} \downarrow$



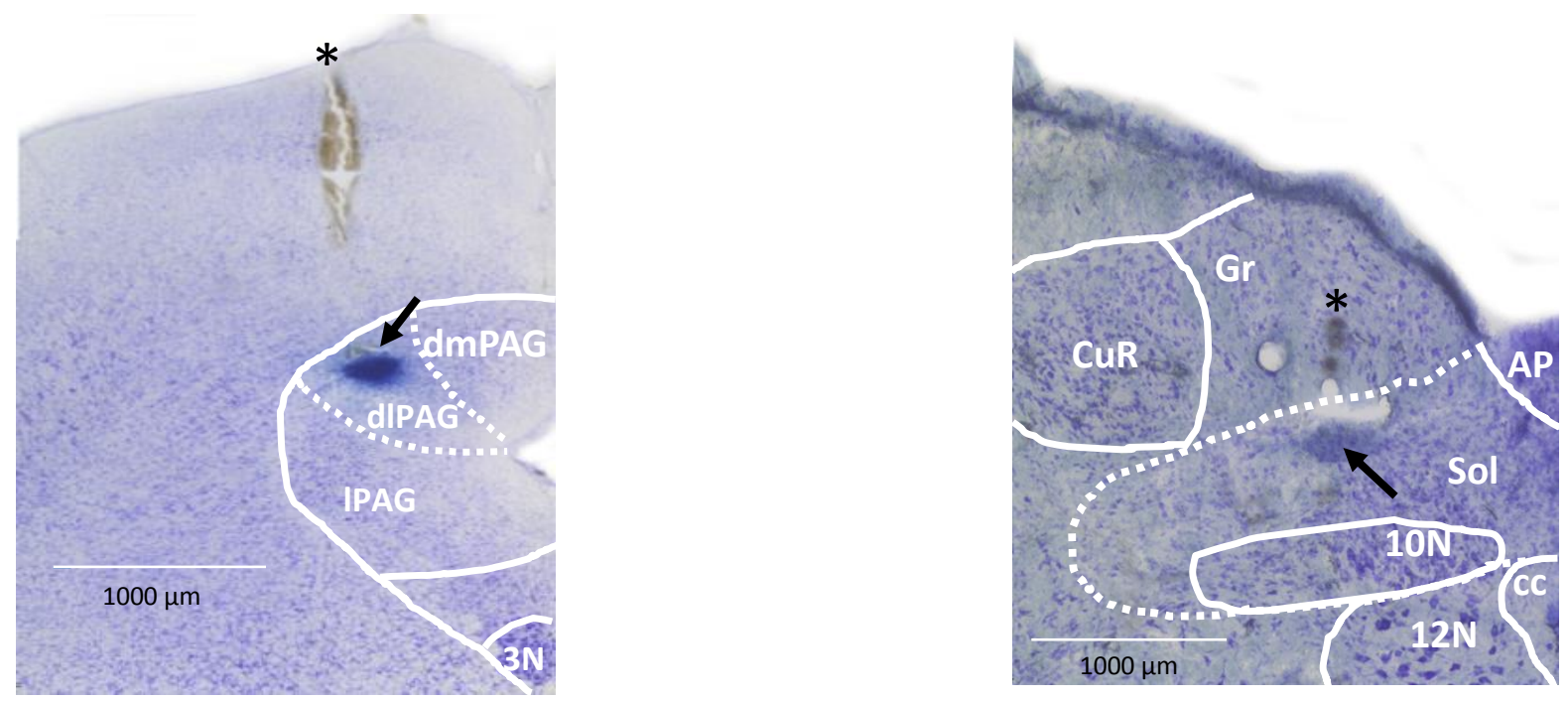
Experiment 2

A
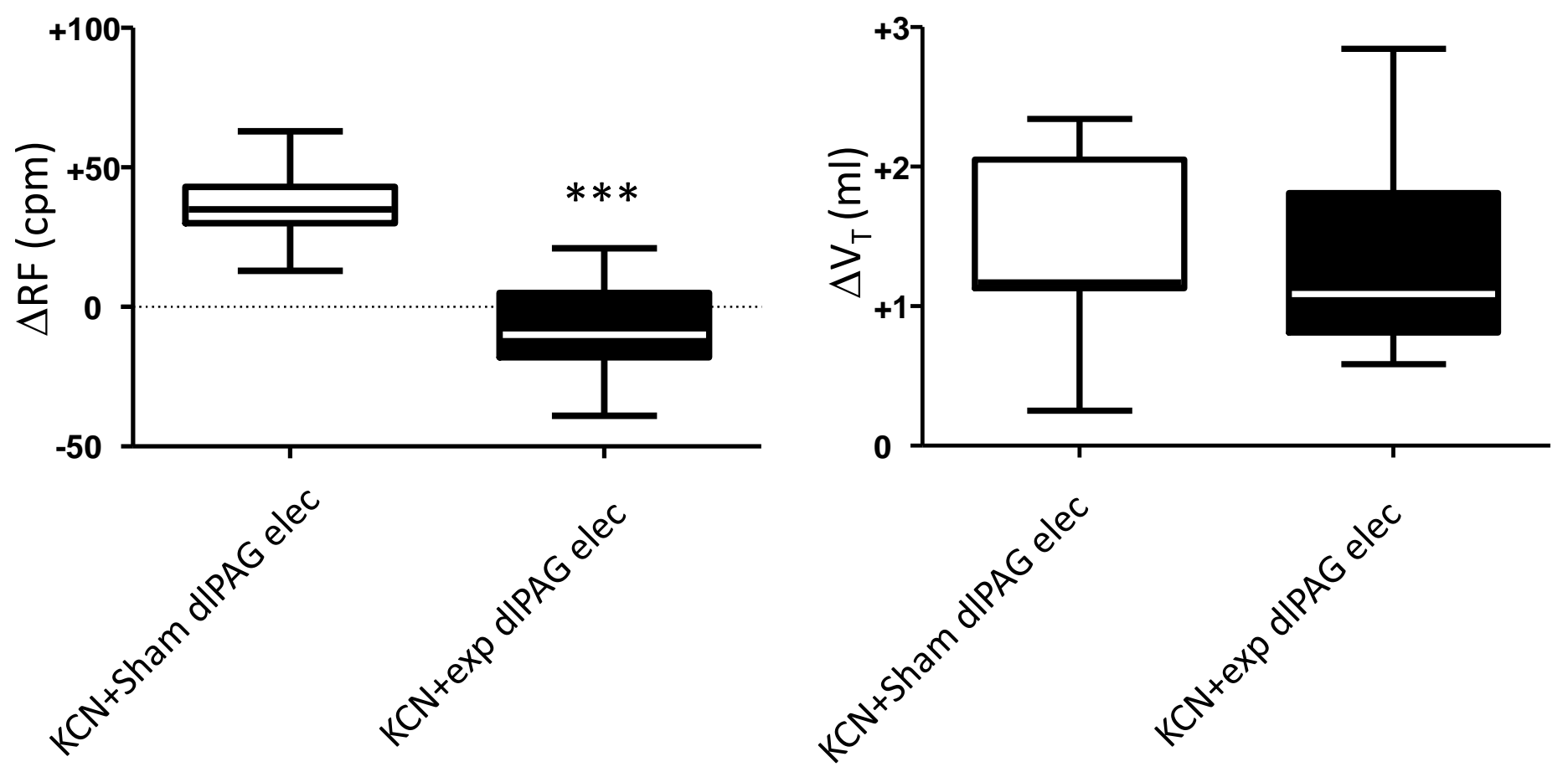

B
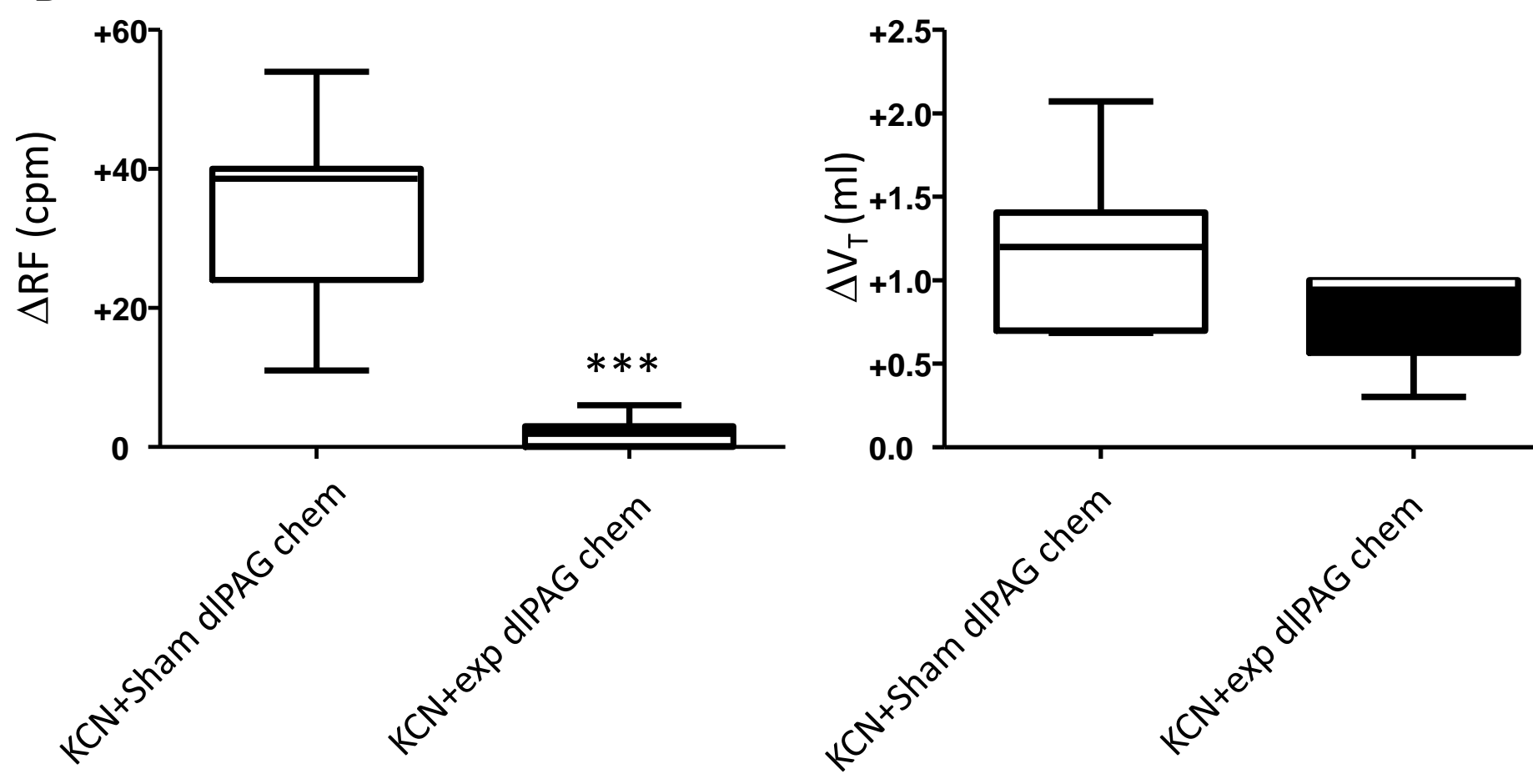
$\mathrm{RF}$ (cpm)

Flow

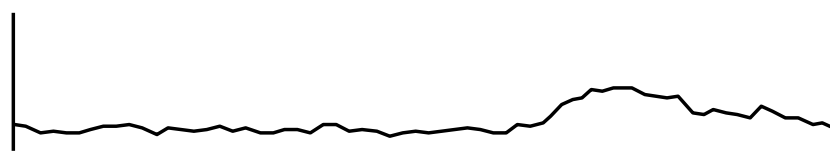

HR (bpm) $\begin{array}{ll}500 \\ 250\end{array}$

ABP $(\mathrm{mmHg})_{50}^{150}$

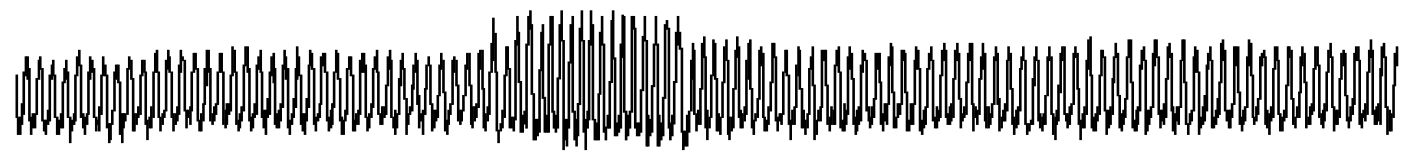

Flow

After intra-NTS vehicle

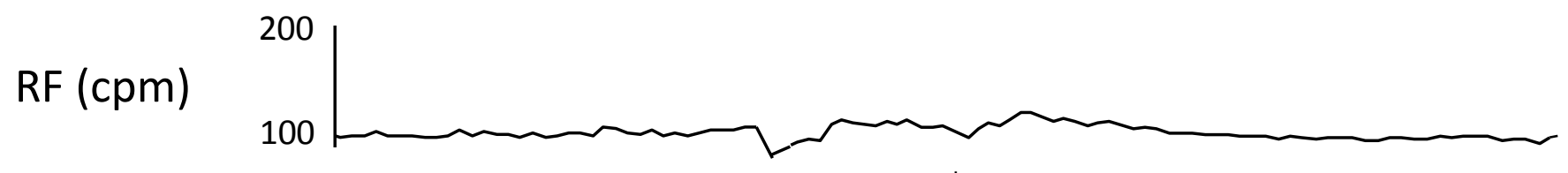
KCN $\uparrow$ Sham dIPAG elec

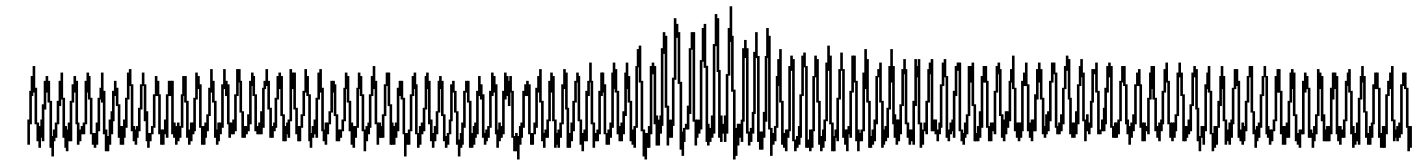

$\mathrm{HR}(\mathrm{bpm}) \quad \begin{array}{r}500 \\ 250\end{array}$

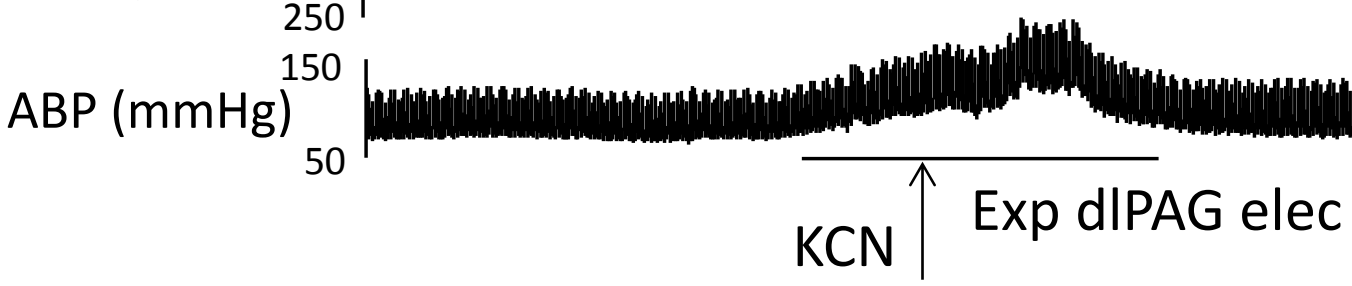

\section{After intra-NTS granisetron (250 pmol)}

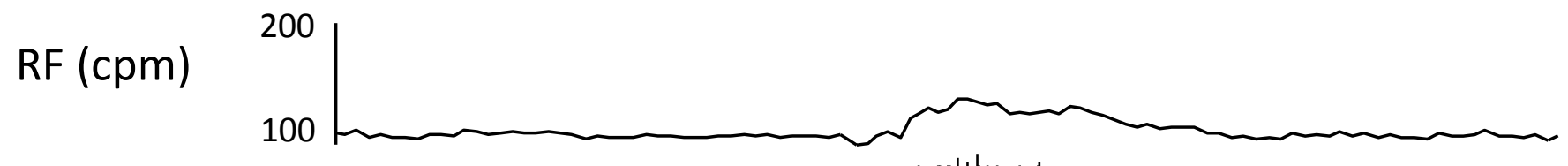

Flow

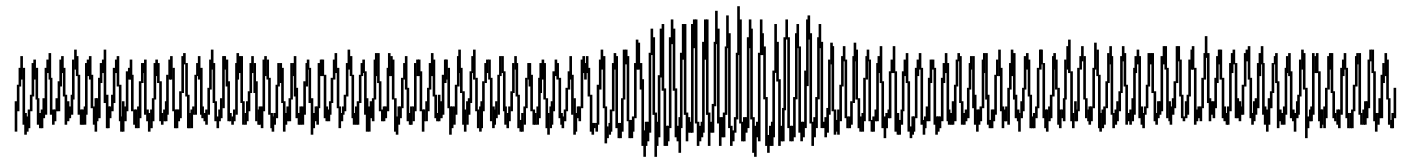

HR (bpm) $\begin{aligned} & 500 \\ & 250\end{aligned}$

ABP $(\mathrm{mmHg})_{50}^{150}$

$$
\begin{array}{lll}
\hline \mathrm{KCN} & \text { Exp dIPAG elec } & \overline{5 \mathrm{sec}}
\end{array}
$$


A
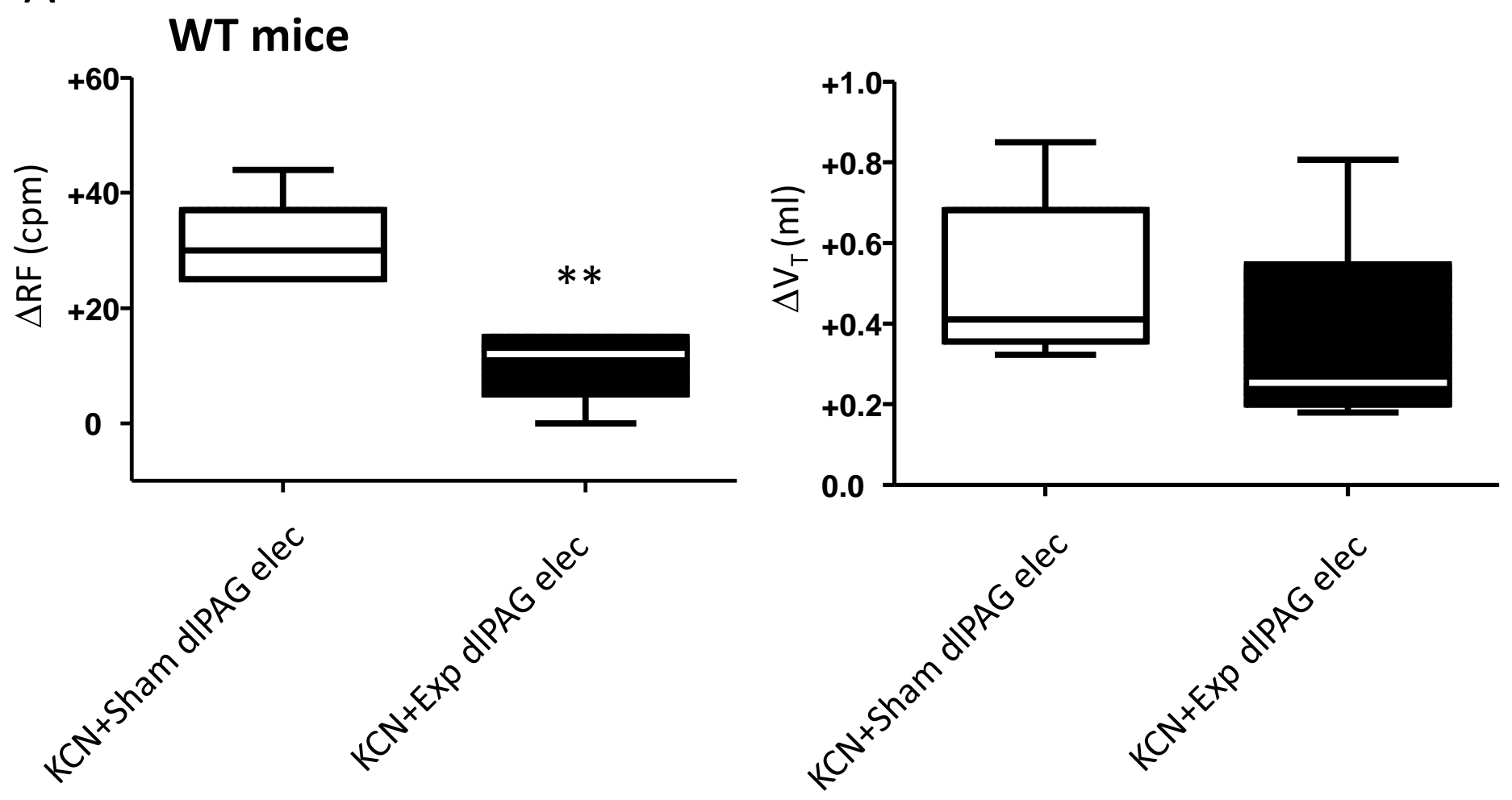

B

5-HT ${ }_{3 а}$ KO
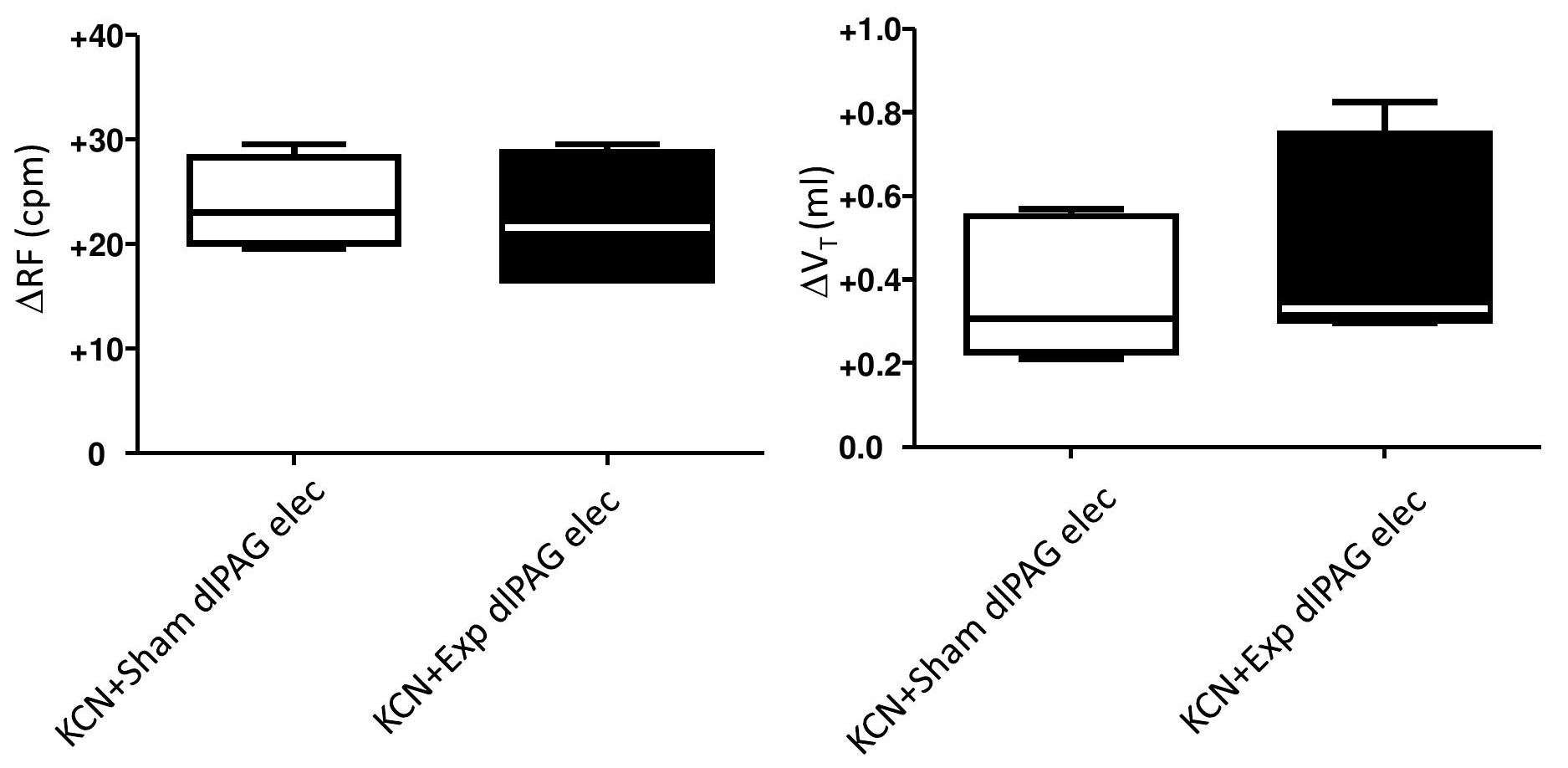
- A hypothalamo-ponto-medullary (HPM) circuit produces hyperventilation and participates to the peripheral chemoreflex respiratory response.

- A new hypothalamo-midbrain-medullary (HMM) circuit observed with mild hypothalamic stimulation only, prevents the peripheral chemoreflex hyperventilatory response.

- The HMM circuit involves the dorsolateral periaqueductal grey matter and $5-\mathrm{HT}_{3}$ receptors in the nucleus tractus solitarius.

- The HMM circuit may be at the origin of the long-term bradypnea induces by emotional stress or observed in diseases caracterised by a reduced chemoreflex response, such as the Congenital Central Hypoventilatory Syndrome. 
Conflict of Interest: none 